\title{
Taxonomy and biostratigraphy of new and emended species of Cenozoic deep-water agglutinated foraminifera from the Labrador and North Seas
}

\author{
F. M. Gradstein ${ }^{1,2}$ and M. A. Kaminski ${ }^{2}$ \\ ${ }^{1}$ Geological Survey of Canada, Bedford Institute of Oceanography, \\ Dartmouth, Nova Scotia B2Y 4A2, Canada \\ ${ }^{2}$ Centre for Marine Geology, Dalhousie University, \\ Halifax, Nova Scotia B3H 3J5, Canada
}

\begin{abstract}
Deep marine, fine grained sedimentary strata of Maastrichtian through Miocene age in the Labrador and North Sea sedimentary basins are rich in agglutinated benthic foraminifera. Six new taxa have been found in these regions, several of which also extend to other circum-Atlantic Paleogene localities. The new taxa are: Ammomarginulina aubertae, n. sp. (Maastrichtian to Eocene), Adercotryma agterbergi, n. sp. (middle Eocene to lower Oligocene), Reticulophragmoides jarvisi (Thalmann) emended herein (Paleocene to lower Oligocene), Reticulophragmoides sp. 5 (Oligocene to Miocene), and Spiroplectammina navarroana Cushman emended herein (Maastrichtian to lower middle Eocene). The last occurrences of these taxa are important elements in the high-resolution probabilistic biozonations for the Labrador and North Sea basins.
\end{abstract}

\section{INTRODUCTION}

As part of a long-term study to increase our understanding of the taxonomy, biostratigraphy, paleobiogeography and paleoecology of deep-water agglutinated foraminifera, we are studying the Cenozoic microfossil assemblages of the Central North Sea, Norwegian-Greenland Sea and Labrador Sea basins. In high-latitude basins in the North Atlantic, the stratigraphic record of calcareous microfossils is often poor and incomplete and the only group of foraminifera with a relatively complete stratigraphic record in the clastic strata are agglutinated foraminifera. One of the primary goals of this project is to establish a high-resolution biostratigraphic framework for the detailed correlation of subsurface strata. A preliminary taxonomic inventory of Cenozoic deep-water agglutinated foraminiferal assemblages from the Labrador and North Sea basins was compiled by Gradstein and Berggren (1981). This pioneering study provided a paleoecologic model (known as the "old bottom water model") for flyschtype agglutinated foraminiferal assemblages. In this model the occurrence of flysch-type agglutinants in slope basins and rapidly subsiding troughs is related to restricted bottom water circulation leading to oxygen-deficient substrates that may limit the occurrence of normal marine taxa and favor instead the development and preservation of agglutinated forms.

In the seven years following the publication of the Gradstein and Berggren (1981) study, our knowledge of agglutinated foraminiferal taxonomy and distribution has steadily improved. Miller et al. (1982) extended the Labrador Margin taxonomic data base into the abyssal Labrador Sea in their study of samples from DSDP Site 112. The taxonomy and biostratigraphy of the deep Labrador Sea was considerably refined using continuously-cored samples from ODP Site 647 . Kaminski et al. (in press) were able to calibrate the biostratigraphy of agglutinated taxa in the Labrador Sea to the magnetostratigraphic record and to the standard nannofossil biozonation, thereby providing age constraints to foraminiferal assemblages on the Labrador Margin. A wealth of prelimi- nary information on the taxonomic and biostratigraphic links between the classic flysch-type faunas described at the end of the last century by J. Grzybowski from the Carpathian flysch deposits, and the classic faunas from the Paleogene of Trinidad and other circum-Atlantic basins was compiled by M. Kaminski (Ph.D. thesis, 1987; Kaminski and Geroch 1987; Kaminski et al. 1988).

Concurrent studies by other workers have provided much needed comparative taxonomic and biostratigraphic data. Verdenius and Van Hinte (1983) independently developed a workable taxonomy and a paleoecologic model for the $\mathrm{Pa}$ leogene bathyal to abyssal agglutinated benthic faunas from Leg 38 DSDP sites in the Norwegian-Greenland Sea. The taxonomy of agglutinated foraminifera from ODP Site 643 (Leg 104) samples from the Norwegian-Greenland Sea was revised by Kaminski (1987) and is further updated in this study. In the Alpine-Carpathian region, Morgiel and Olszewska (1981) illustrated and reported the biostratigraphic ranges of agglutinated taxa, and the study by Geroch and Nowak (1984) provided the basis for the first formal Tithonian to Eocene zonation based on agglutinated foraminifera. This zonation based on first and last occurrences has found applications at other Tethyan localities such as Morocco (Kuhnt 1987), northern Italy (Morlotti 1988), and at abyssal ODP sites in the North Atlantic (Moullade et al., in press).

Preliminary probabilistic zonations using the diversified record of microfossil last occurrences in the Labrador and North Sea basins were published by Gradstein et al. (1985), D'Iorio (1986) and by Gradstein et al. (1988). The stratigraphic distribution of the deep marine, fine-grained clastic wedges in these two basins was controlled by the local rifting and early opening phases in late Cretaceous and early Cenozoic time. Post-rift, deep-marine (bathyal) conditions prevailed locally on the Labrador Shelf from the Maastrichtian to the Eocene, and in the North Sea from the middle Paleocene to Miocene. The Labrador and Norwegian-Greenland Sea oceanic basins 
subsided to abyssal depths during the late Paleocene and early Eocene.

The main focus of this report is to document six new and emended species of agglutinated foraminifera which have useful biostratigraphic ranges in Cenozoic deep-marine sediments of the North Sea and Labrador Sea. Three of these taxa are formally described as new species and one species, emended herein, is placed in a new genus.

\section{SAMPLE MATERIAL}

The Labrador and North Sea basins have been sampled by numerous exploratory wells. For this study, we made a selection of 31 Central North Sea and 27 Labrador Margin/ Grand Banks wells. The North Sea wells have superior sampling, including numerous cores. In total, over 11,000 cuttings, sidewall cores and conventional core samples were analyzed (Table 1) mainly by the senior author (FMG) and assisted by the junior author (MAK) and W. A. Berggren (Woods Hole). In addition, MAK studied the biostratigraphy of agglutinated foraminifera based on detailed analysis of 670 samples from 14 wells and one outcrop section in different areas of the North Atlantic. In order to standardize our taxonomy relative to the classic taxonomic studies carried out in Poland and Trinidad mentioned earlier, we made direct microscopic comparisons between specimens observed in the wells and specimens from other localities. The total Maastrichtian to middle Miocene agglutinated foraminiferal fauna of the Labrador and Central North Sea includes over 125 taxa (Appendix 1). At least half of these taxa are relatively common.

In order to supplement our knowledge of the geographic and biostratigraphic distribution of these taxa, we sampled ODP cores from the Norwegian-Greenland Sea. The most complete continuously-cored Paleogene section available for benthic foraminiferal analysis is ODP Site 643 on the Vøring slope. Site 643 is located at $67^{\circ} 42.9^{\prime} \mathrm{N}, 01^{\circ} 02.0^{\prime} \mathrm{E}$ at a water depth of $2768 \mathrm{~m}$ on magnetic anomaly $23 / 24$, which is the oldest oceanic crust in the region. Hole $643 \mathrm{~A}$ penetrated $565.2 \mathrm{~m}$ of sediment, including approximately $165 \mathrm{~m}$ of Eocene sediments and $125 \mathrm{~m}$ of Oligocene to lower Miocene sediments. Sediments from Hole $643 \mathrm{~A}$ were subdivided into 5 lithologic units by the shipboard scientific party. For this study, we sampled Lithologic Unit 5, which occurs between 400.7 and 565.2 meters below sea floor (mbsf), and the lowermost part of Lithologic Unit 4, occurring between 274.5 and $400.7 \mathrm{mbsf}$. A total of 63 samples from Hole $643 \mathrm{~A}$ were analyzed for benthic foraminifera. The biostratigraphy of agglutinated taxa in these samples was reported by Kaminski (1987).

\section{TAXONOMY}

In this study we formally describe four new taxa (three new species and one new genus), emend two existing species, and describe one new species which we leave in open nomenclature pending the recovery of this taxon in more wells. These taxa are:

Adercotryma agterbergi Gradstein and Kaminski, n. sp. Ammomarginulina aubertae Gradstein and Kaminski, n. sp. Dorothia seigliei Gradstein and Kaminski, n. sp.
Reticulophragmoides Gradstein and Kaminski, n. gen.

Reticulophragmoides jarvisi (Thalmann), emend. Gradstein and Kaminski

Reticulophragmoides sp. 5

Spiroplectammina navarroana Cushman, emend. Gradstein and Kaminski

All holotypes have been deposited in the "Cushman Collection" which is housed in the U.S. Natural History Museum, Smithsonian Institution, Washington, D.C. Additional paratypes and metatypes have been sent to the micropaleontological collection of the Natural History Museum in Vienna, Austria (under the supervision of Dr. Fred Rögl), and to the micropaleontological collection of the Jagiellonian University in Kraków, Poland (under the supervision of Dr. Stanislaw Geroch). Additional paratype specimens remain in the authors' collections at the Bedford Institute of Oceanography, Dartmouth, Nova Scotia.

Adercotryma agterbergi Gradstein and Kaminski, n. sp.

Plate 1, figures $1 \mathrm{a}-5 \mathrm{c}$; plate 2 , figures $1 \mathrm{a}-3 \mathrm{~b}$; text-figure 1

Type specimen: Holotype (USNM 429107) and several paratypes (USNM 429108) are deposited in the micropaleontological collections of the U.S. Natural History Museum, Washington, D.C. Additional specimens (metatypes) are deposited at the Natural History Museum in Vienna, Austria (MI-616); at the Jagiellonian University in Kraków, Poland, and in the authors' collections.

Type level: Upper Eocene to lower Oligocene (R. amplectens zone to $R$. bulimoides- $D$. seigliei zone).

Type locality: Holotype and paratypes are from the Central North Sea, UK Block 30, Shell 30/19-1 well, 8270-8850 ft.

Derivation of name: Named in honor of Dr. Frits Agterberg (GSC Ottawa).

Diagnostic features: Test free, planispiral, asymmetric, with subglobular chambers elongated normal to the coiling axis. Test consists of 2 to $2 \frac{1}{2} 2$ whorls with four chambers in the last whorl. Dorsal (spiral) side is flat, with chambers in the early whorl visible. Ventral side is highly convex with involute coiling. Sutures are distinct, incised and slightly curved in the ventral side. The aperture is indistinct, but in some specimens an umbilical flap is visible on the ventral side. Wall is medium-coarse to finely agglutinated.

Size: Small, usually less than 300 microns in diameter. Diameter of holotype: 200 microns, height of last chamber: 175 microns.

Observed occurrences: Adercotryma agterbergi, n. sp. occurs commonly in wells from the Central North Sea, where it ranges from the middle to upper Eocene $R$. amplectens zone to the lower Oligocene $R$. bulimoides- $D$. seigliei zone. We have also observed it in the middle Eocene to lower Oligocene of ODP Hole 643A on the Vøring Plateau.

Known stratigraphic range: Middle Eocene to lower Oligocene.

Bathymetric range: Bathyal.

Remarks: Adercotryma agterbergi, n. sp. differs from the recent species $A$. glomerata (Brady) in having a less conical 
TABLE 1

\begin{tabular}{|c|c|c|c|}
\hline \multicolumn{2}{|c|}{ Central North Sea } & \multicolumn{2}{|c|}{ Labrador Margin/Grand Banks } \\
\hline Well Name: & Interval Studied: & Well Name: & Interval Studied: \\
\hline Conoco 211/19-1 & $2000-5925^{\prime}$ & Rut H-11 & $675-4070 \mathrm{~m}$ \\
\hline Total 3/9A-1 & $1355-2180 \mathrm{~m}$ & Karlsefni H-13 & $1300-6100^{\prime}$ \\
\hline Total 3/25-1 & $554-2580 \mathrm{~m}$ & Snorri J-90 & $1260-9820^{\prime}$ \\
\hline Total 9/10b-1 & $1682-2952 \mathrm{~m}$ & Herjolf M-92 & $3750-7790^{\prime}$ \\
\hline Shell $9 / 23-1$ & $900-6700^{\prime}$ & Ogmund E-72 & $490-1595 \mathrm{~m}$ \\
\hline Mobil 9/13-1 & $1800-8700^{\prime}$ & Bjarni H-81 & $2270-6270^{\prime}$ \\
\hline Mobil 9/13-3A & $990-8840^{\prime}$ & North Leif I-05 & $490-2535 \mathrm{~m}$ \\
\hline Mobil 9/13-5 & $1600-8900^{\prime}$ & S. Labrador N-79 & $1230-3215 \mathrm{~m}$ \\
\hline Dansk Nordso A-2 & $4650-6080^{\prime}$ & Roberval K-92 & $635-3000 \mathrm{~m}$ \\
\hline Dansk Nordso E-1 & $4400-6698^{\prime}$ & Cartier O-70 & $2270-6270^{\prime}$ \\
\hline Dansk Nordso E-2 & $4710-6470^{\prime}$ & Gudrid H-55 & $1660-8700^{\prime}$ \\
\hline BP $14 / 4-1$ & $280-989 \mathrm{~m}$ & Indian Harbour M-52 & $1740-10,700^{\prime}$ \\
\hline BP $14 / 15-2$ & $509-1931 \mathrm{~m}$ & Freydis B-87 & $1660-8700^{\prime}$ \\
\hline BP $15 / 20-1$ & $1240-1966 \mathrm{~m}$ & Hare Bay E-21 & $393-3200^{\prime}$ \\
\hline BP $15 / 20-2$ & $870-2343 \mathrm{~m}$ & Bonavista C-99 & $1860-12,040^{\prime}$ \\
\hline BP $21 / 10-1$ & $4970-7980^{\prime}$ & Cumberland B-55 & $2190-11,830^{\prime}$ \\
\hline BP $21 / 10-4$ & $1217-2808 \mathrm{~m}$ & Dominion $\mathrm{O}-23$ & $1380-9320^{\prime}$ \\
\hline BP $16 / 11-1$ & $793-2200 \mathrm{~m}$ & Egret K-36 & $860-1940^{\prime}$ \\
\hline Esso Norway $16 / 1-1$ & $1250-9025^{\prime}$ & Adolphus D-50 & $1140-8520^{\prime}$ \\
\hline Phillips $2 / 7-1 \mathrm{x}$ & $2030-9700^{\prime}$ & Flying Foam I-13 & $990-6200^{\prime}$ \\
\hline Phillips $16 / 17-1$ & $3579-9500^{\prime}$ & Blue $\mathrm{H}-28$ & $2090-4760^{\prime}$ \\
\hline Phillips $16 / 29-2$ & $2000-8945^{\prime}$ & Hibernia P-15 & $255-1200^{\prime}$ \\
\hline Mobil 21/28-1 & $2090-4600^{\prime}$ & Bonanza M-71 & $1210-3405 \mathrm{~m}$ \\
\hline Shell $22 / 6-1$ & $1480-8200^{\prime}$ & South Tempest G-88 & $740-2655 \mathrm{~m}$ \\
\hline Phillips 22/14-1x & $3400-9875^{\prime}$ & & \\
\hline Phillips $23 / 22-1$ & $1525-10,125^{\prime}$ & & \\
\hline Amoco Norway 2/8-1 & $1190-8210^{\prime}$ & & \\
\hline Shell 29/3-1 & $1420-9300^{\prime}$ & & \\
\hline Phillips 30/19-1 & $525-10,102^{\prime}$ & & \\
\hline Shell 30/19-1 & $1410-10,500^{\prime}$ & & \\
\hline Amoco 38/16-1 & $1480-3870^{\prime}$ & & \\
\hline
\end{tabular}

ventral side, and in having a flap covering the umbilicus that is visible in most well-preserved specimens.

Ammomarginulina aubertae Gradstein and Kaminski, n. sp. Plate 3, figures 1-8; plate 4, figures 1-3; text-figure 2

Ammobaculites aff. polythalamus Loeblich.-GRADSTEIN and BERGGREN 1981, p. 253, pl. 4, figs. 6-8.

Type specimen: Holotype (USNM 429109) and several paratypes (USNM 429110 and 429111) are deposited in the micropaleontological collections of the U.S. Natural History
Museum, Washington, D.C. Additional specimens (paratypes and metatypes) are deposited at the Natural History Museum in Vienna, Austria (MI-617 and 618); at the Jagiellonian University in Kraków, Poland, and in the authors' collections.

Type level: Early to middle Eocene (S. patagonica zone to $R$. amplectens zone).

Type locality: Central North Sea, UK Blocks 22 and 30. Holotype is from Shell 30/19-1 well, 8727-9160 ft (S. pa-

\section{PLATE 1}

Adercotryma agterbergi, n. sp.

1a-c Holotype, North Sea, UK Block 30, Shell 30/19-1 well, 8270-8320', × 130 . 4a-5c Paratypes, North Sea, UK Block 29, Shell 29/3-1 well, 7410-7710', × 130 .

2a-3c Paratypes, North Sea, UK Block 30, Shell 30/19-1 well, 8270-8320', × 130 . 


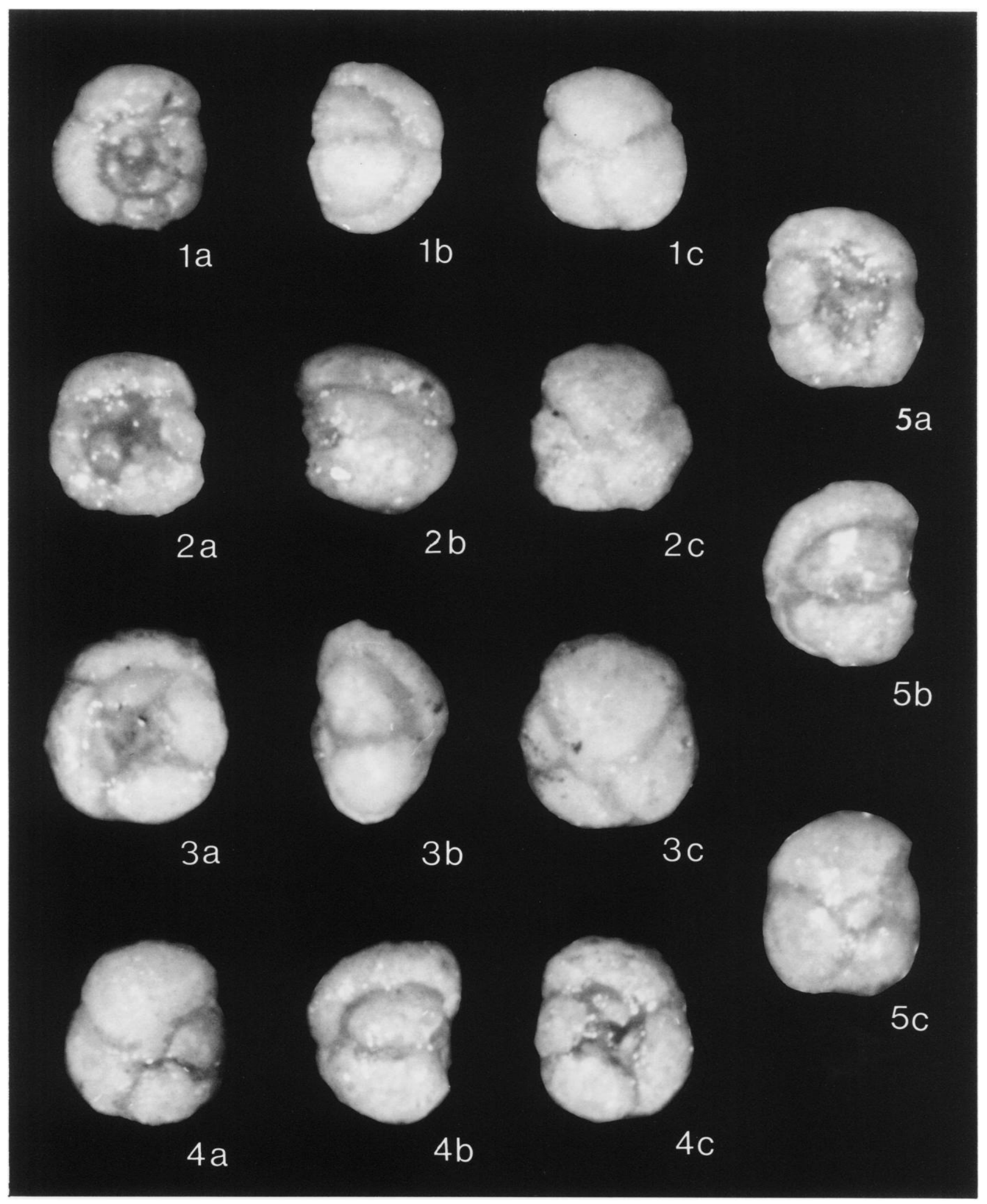



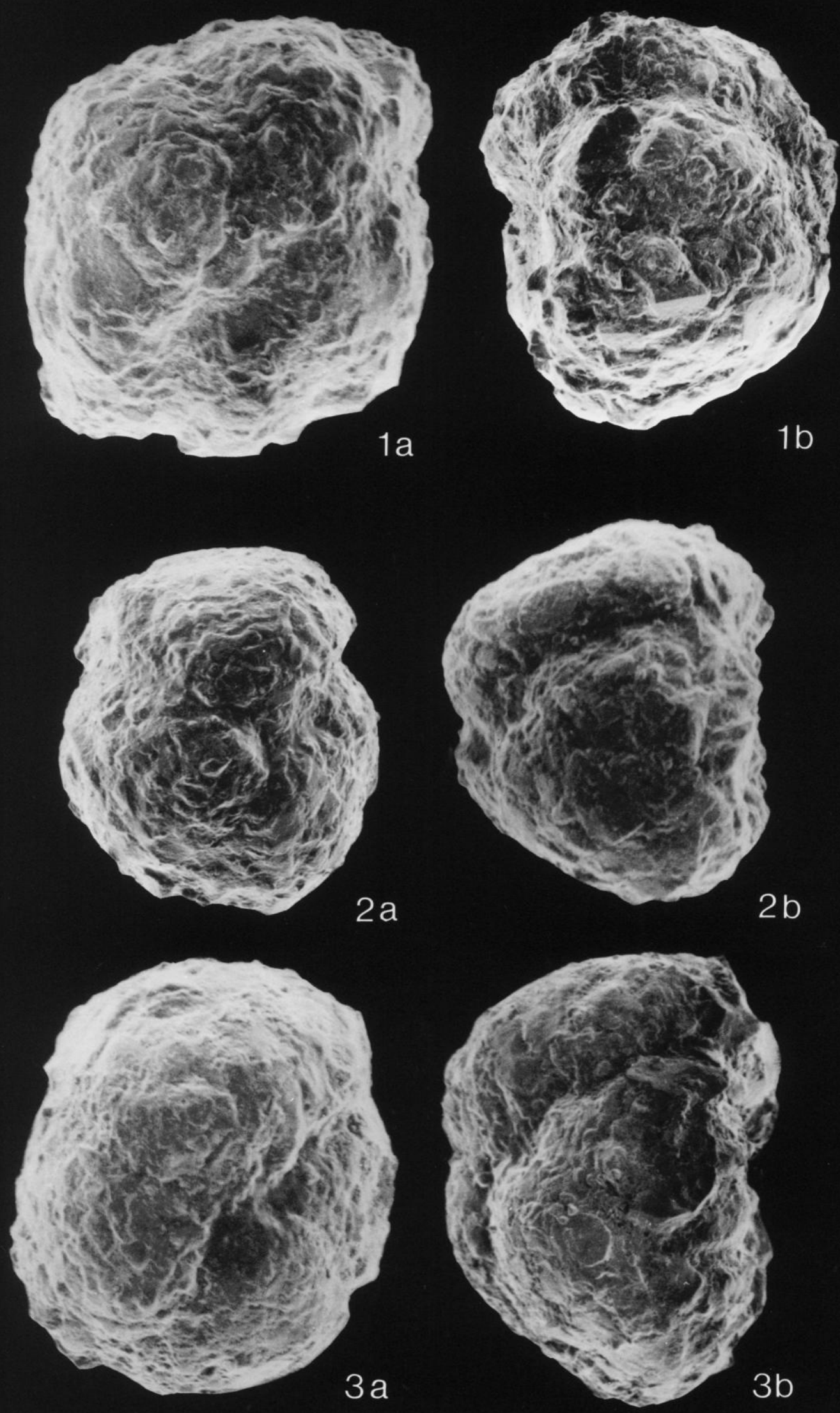
tagonica zone to $R$. amplectens zone). Figured paratypes are from the Shell 22/6-1 well, 6356-6820 ft ( $R$. amplectens zone).

Derivation of name: Named in honor of Ms. Jane Aubert (Pau, France).

Diagnostic features: Test free, initial part consisting of an evolute planispiral coil of more than one whorl, with an open umbilicus and coil suture, with 10 to 18 chambers in the last whorl (average 14). Sutures are slightly depressed and may be slightly curved or sigmoidal in the planispiral part. In well-preserved specimens, sutures stand out as dark lines when viewed on a dark background. The periphery is rounded and may be slightly lobate at the sutures. Chambers increase in size slowly. The uncoiled part of the test, when present, is usually short and extends tangentially from the coiled part in the plane of coiling. The sutures in the uniserial part are generally oblique and are flush with the surface of the test. In some specimens, the uncoiled part is situated asymmetrically atop the planispiral part. In this case, the chambers may be uniserial or may be arranged in a staggered manner, suggesting biseriality. The apertural face may be flat or slightly convex and is oval in outline. The aperture in the spiral part is areal and raised on a short neck at the top of the apertural face. As a result, the chambers in the spiral part are connected by a U-shaped tube which is expressed on the exterior as a peripheral lobe. This lobe may possess a bulbous swelling. The aperture in the uncoiled portion is terminal, at the dorsal side of the apertural face. The wall is medium to finely agglutinated, with much cement. The agglutinated grains are mostly quartz.

Size: (Holotype) length $0.37 \mathrm{~mm}$, width $0.26 \mathrm{~mm}$, height of chambers $0.03 \mathrm{~mm}$. Length of largest specimen in our collections: $0.60 \mathrm{~mm}$.

Observed occurrences: Ammomarginulina aubertae, n. sp. is apparently a high-latitude species restricted to the North Sea and Labrador Margin. It was recorded as Ammobaculites aff. polythalamus from the upper Paleocene (R. paupera-T. ruthven murrayi zone) to the lower part of the middle to upper Eocene $R$. amplectens zone of the Central North Sea by Gradstein and Berggren (1981). We have confirmed this range using more North Sea wells. Ammomarginulina aubertae, $\mathrm{n}$. $\mathrm{sp}$. is more common in the $R$. amplectens zone but it occurs below the tuff horizons in the Forties area of the North Sea. In Labrador Margin wells, it ranges from upper Maastrichtian (A. mayaroensis zone) to the upper Eocene ( $R$. amplectens$T$. pomeroli zone). D'Iorio (1986) determined its average last occurrence at ca. $40 \mathrm{Ma}$ on the Labrador Margin. Despite our efforts to locate this species at other localities, we have
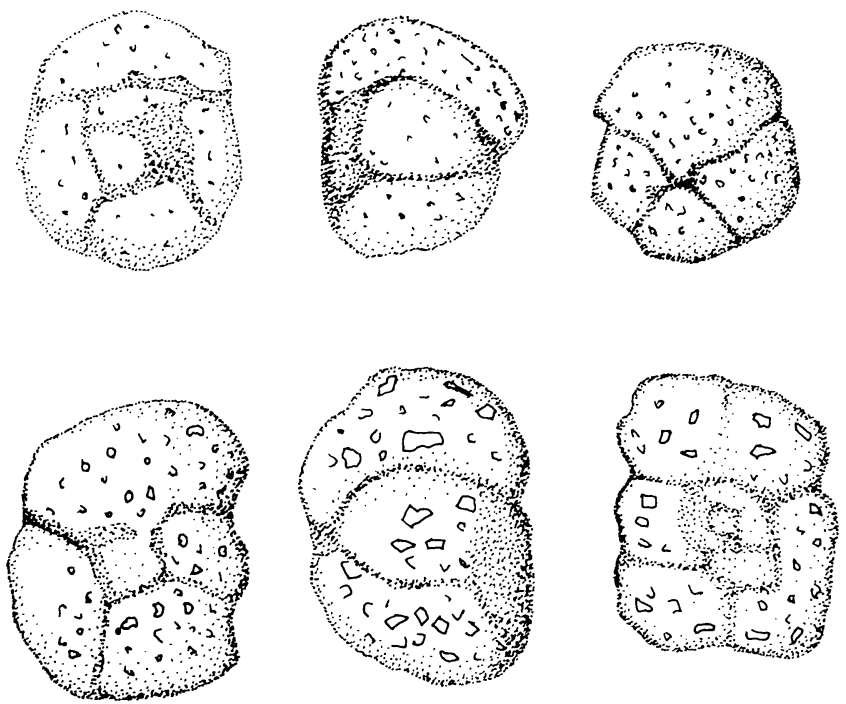

TEXT-FIGURE 1

Paratypes of Adercotryma agterbergi, n. sp.

not observed it in our samples from DSDP sites, the western Tethys, or Trinidad.

Known stratigraphic range: Maastrichtian to Eocene. The last occurrence of this taxon is a useful indicator of Eocene strata in the North Sea and Labrador Sea.

\section{Bathymetric range: Bathyal.}

Remarks: Specimens of $A$. aubertae, n. sp. with well-developed uniserial portions, such as those illustrated in plate 3 , are rare. Accordingly, our choice of a holotype specimen reflects the type of specimen that is commonly encountered. This specimen has at most one uniserial chamber. Specimens from the Maastrichtian and Paleocene of the Labrador Margin have an average of 12 chambers in the last whorl of the planispiral part. We have not observed any specimens with well-developed uniserial portions in our material from the Labrador Sea. These specimens also have coarser material incorporated into the wall than specimens from the North Sea. As a consequence, the internal structure of the Labrador specimens is less distinct and their external morphology is more irregular. Although the Labrador specimens also occur in stratigraphically older horizons, we believe the differences in morphology are not sufficiently great to warrant the creation of subspecies.

\section{PLATE 2}

Adercotryma agterbergi, n. sp.
1a, b Paratype, North Sea, UK Block 16, Shell 16/1-1
2a-3b Paratypes, North Sea, UK Block 29, Shell 29/3-1 well, $5100^{\prime}, \times 790$. well, 7410-7110', ×790. 

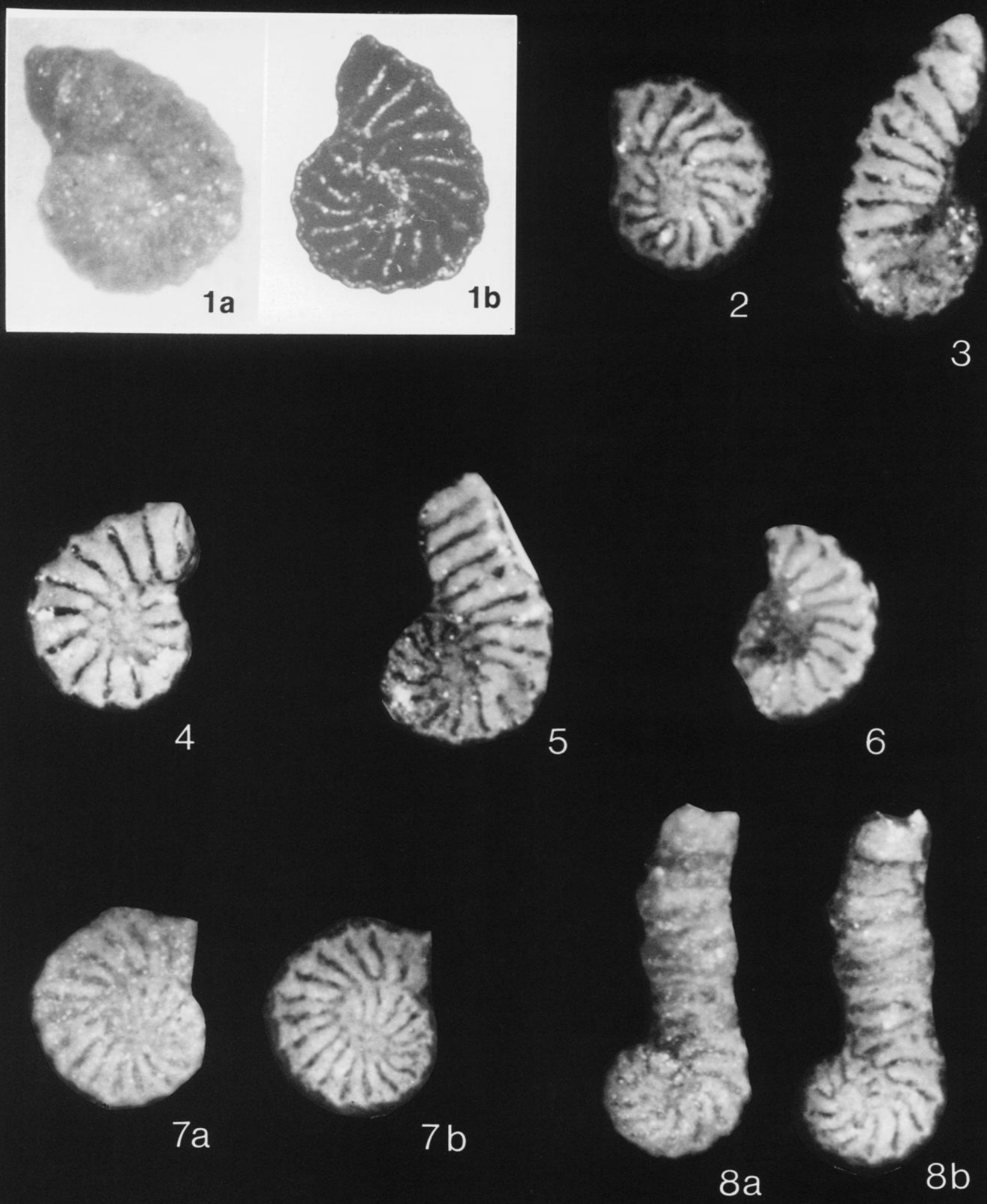

5

6

PLATE 3

Ammomarginulina aubertae, $\mathrm{n}$. sp.

la, b Holotype, North Sea, UK Block 30, Shell 30/19-1 well, $\times 105$. 2-8b Paratypes, North Sea, UK Block 22, Shell 22/6-1 well, 6356-6820', × 105 . 
Ammomarginulina aubertae, n. sp. differs from Ammobaculites polythalamus Loeblich from the upper Cretaceous of Texas in possessing more whorls and more numerous chambers in the spiral part, and in its smaller, lower chambers in the uniserial part. Ammobaculites yumotoensis Asano from the Oligocene of Japan differs from $A$. aubertae, n. sp. in having fewer chambers and straight sutures in the spiral part. Ammobaculites chiranus Cushman and Stone from the Eocene of Peru differs in its larger size (to $2 \mathrm{~mm}$ ) and in possessing chambers which increase in size more rapidly and lack oblique sutures in the uniserial part. Ammomarginulina macrospira Bykova from the Eocene of Soviet Central Asia differs in having fewer (only 5 or 6 ) chambers in the spiral part.

Dorothia seigliei Gradstein and Kaminski, n. sp.

Plate 5, figures 1-6; plate 6 , figures 1-5; text-figure 3

“Dorothia" sp. 6 GRADSTEIN and BERGGREN 1981, p. 261, pl. 5, figs. 8,9 .

Karreriella siphonella (Reuss). - VERDENIUS and VAN HINTE 1983, p. 196, pl. 7, figs. 11, 12, 14, 15.

Type specimen: Holotype (USNM 429112) and several paratypes (USNM 429113) are deposited in the micropaleontological collections of the U.S. Natural History Museum, Washington, D.C. Additional specimens (paratypes and metatypes) are deposited at the Natural History Museum in Vienna, Austria (MI-619); at the Jagiellonian University in Kraków, Poland, and in the authors' collections.

Type level: Lower Oligocene (R. bulimoides-D. seigliei zone).

Type locality: Central North Sea, UK Blocks 29 and 30. Holotype is from the Shell 30/19-1 well, $8200 \mathrm{ft}$; paratypes are from the Shell 29/3-1 well, 6980-7220 ft.

Derivation of name: Named in honor of Dr. George Seiglie (Chevron USA).

Diagnostic features: Test free, initially trochospiral with $31 \frac{1}{2}$ chambers in the initial whorl, reducing to three, and finally two chambers. In well-preserved specimens the test is conical and round in cross-section, but most specimens are compressed flat. Chambers are few, with only two triserial whorls and at most two biserial whorls. Specimens average 11 chambers total. Chambers increase in size rapidly and may be somewhat inflated. The aperture in the triserial part is a small, rounded opening located near the umbilicus, on a short neck. In the biserial part, the aperture is an oval or crescentshaped opening near the base of the last chamber, surrounded by a lip. The wall is thin, very finely agglutinated, with much cement.

Size: Relatively small, generally less than 500 microns. Length of holotype: 300 microns. Diameter across apertural face: 320 microns.

Observed occurrences: Verdenius and Van Hinte (1983) recorded this species as Karreriella siphonella from the Oligocene and lower Miocene of DSDP Hole 345 in the Lofoten Basin and from the Oligocene and Miocene of DSDP Site 348 in the Norwegian-Greenland Sea. The specimens illustrated by Verdenius and Van Hinte correspond closely to our specimens, but we have not been able to verify its stratigraphic range in Holes 345 and 348 . We have observed $D o$ - rothia seigliei, n. sp. in the upper Eocene and Oligocene of ODP Site 643 on the Vøring Slope (Norwegian-Greenland Sea), and in the upper Eocene to lower Oligocene of the Central North Sea. Its average last occurrence in the North Sea is in the lower portion of the lower Oligocene (lower portion of the $R$. bullimoides-D. seigliei zone), near or below the last occurrence of $R$. bulimoides). This species appears to be geographically restricted to the North Sea and Norwegian-Greenland Sea.

Known stratigraphic range: Upper Eocene to Oligocene; possibly to Miocene at DSDP sites in the Norwegian-Greenland Sea.

Bathymetric range: Bathyal.

Remarks: Because of its thin wall, Dorothia seigliei, n. sp. is usually compressed in any plane. As a result, specimens which are laterally compressed appear to have broadly rounded chambers in the final whorl (pl. 5, figs. 3, 6). Uncompressed specimens, such as the holotype (pl. 5, figs. 1a-c) and specimens which are compressed in the axis of coiling (pl. 5, figs. 4,5 ) have a relatively flat apertural face.

Dorothia seigliei, n. sp. differs from Dorothia indentata (Cushman and Jarvis) by its smaller size and fewer chambers. The two species also have disjunct stratigraphic ranges. Dorothia brevis Cushman and Stainforth from the Oligocene of Trinidad may resemble $D$. seigliei in outline, but differs in becoming more quickly biserial and in its low, broad aperture. Dorothia germanica Cushman from the lower Oligocene Septarian clay of Germany (Hermsdorf near Berlin; Cushman Collection 20883) differs in having more numerous chambers in the biserial part, chambers which increase in size more slowly, a less conical outline, and a more coarsely agglutinated test. Dorothia textilarioides (Hantken) from the lower Oligocene of Hungary differs in its more elongate test (chambers are less globular and do not overlap as strongly as in D. seigliei, n. sp.), more numerous chambers, and coarser, thicker wall.

\section{Reticulophragmoides Gradstein and Kaminski, n. gen.}

Type species: Nonion jarvisi Thalmann (see synonymy of $R$. jarvisi below).

Diagnostic features: Test free, multilocular, planispirally coiled, with limbate sutures and umbilical boss. A blind tubular extension of the chamber protrudes into the umbilical region. Chambers may develop simple alveolar structure in later chambers. Aperture interiomarginal (Haplophragmoides-like), without a lip or supplementary pores.

Observed occurrences: Paleogene of the North Atlantic region.

Remarks: Reticulophragmoides, n. gen. is transitional in morphology between Haplophragmoides and Reticulophragmium. Its distinguishing feature is its limbate sutures and the blind umbilical tube. We recognize two species of Reticulophragmoides ( $R$. jarvisi and $R$. sp. 5). The type species, Reticulophragmium jarvisi (Thalmann) evolved from a Haplophragmoides ancestor during the middle Paleocene. Younger specimens of $R$. jarvisi develop a few alveoles in later chambers. A second species from the upper Paleogene of the North Sea, Reticulophragmoides sp. 5, has more alveoles than R. jarvisi. 

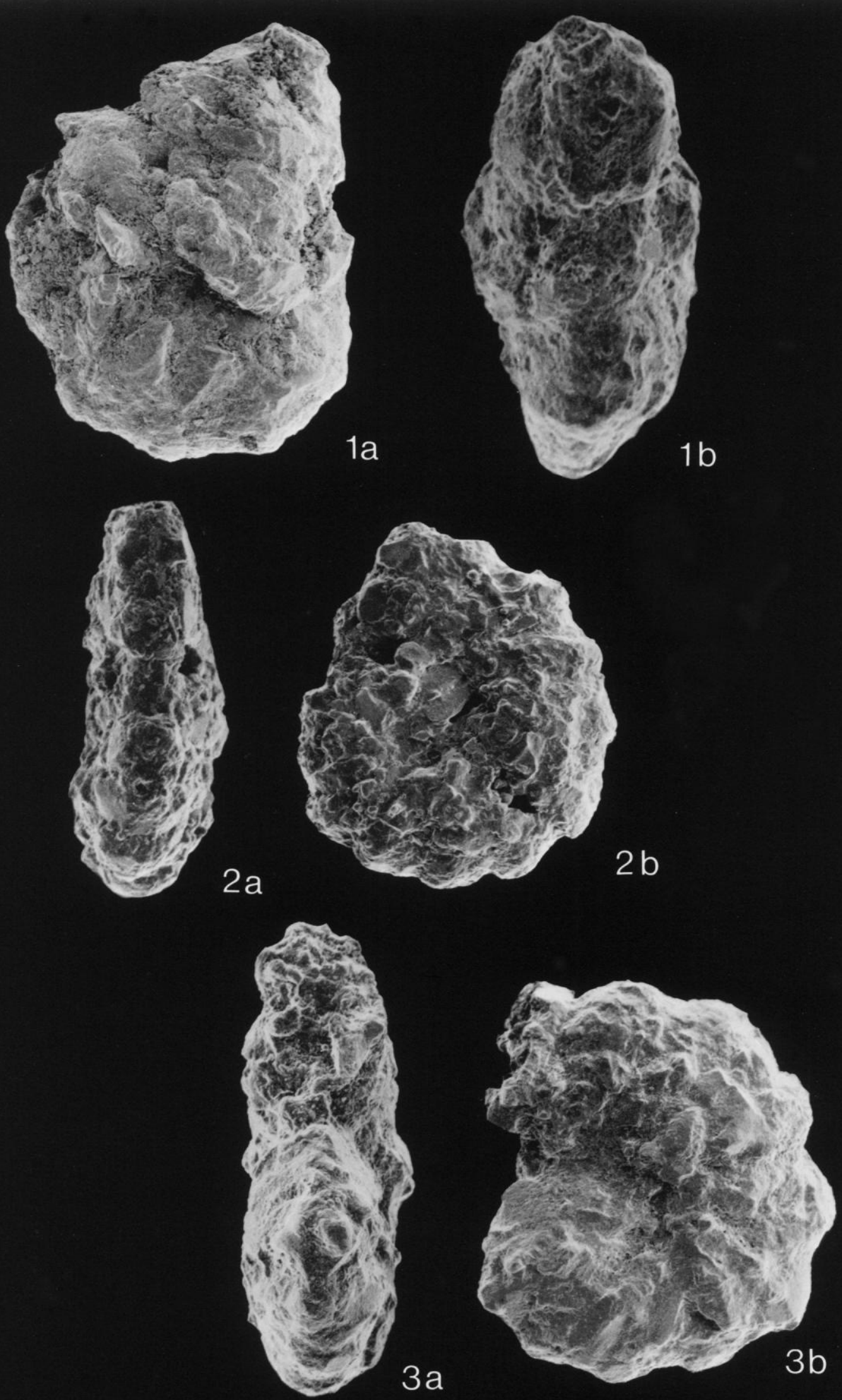
Reticulophragmoides jarvisi (Thalmann) emend.

Plate 7, figures 1a-8; text-figure 4

Nonion cretacea CUSHMAN and JARVIS 1932, p. 41, pl. 12, figs. $12 \mathrm{a}, \mathrm{b}$.

Nonion jarvisi (new name) THALMANN 1932, pp. 312-313.

Haplophragmoides(?) jarvisi (Thalmann). -KAMINSKI et al. 1988, pl. 7, figs. $1 \mathrm{a}-2 \mathrm{~b}$.

Type specimen: The holotype is housed under Nonion cretaceum (Cushman Collection 15327) in the U.S. Natural History Museum, Washington, D.C.

Type level: Upper Paleocene, zone P5.

Type locality: Lower Lizard Springs Formation, from a pit at Lizard Springs, Trinidad.

Diagnostic features: Test free, planispirally coiled, biconvex, thickest near the umbilicus, with 6 to 9 chambers in the last whorl. Periphery is acute, circular to slightly lobate in outline, with a keel. Sutures are depressed, slightly curved, and strongly limbate. The umbilical region has a well-developed boss. A tubular lobe of the chamber that ends in a blind canal protrudes into the umbilical region and is expressed at the surface as a glassy elevated area. Chambers are usually simple, but specimens from stratigraphically younger horizons may develop simple alveolar structure in later chambers. The aperture is interiomarginal (Haplophragmoides-like) without a lip or supplementary pores. The apertural face contains relatively larger agglutinated grains as in many species of $R e$ ticulophragmium. The wall is finely agglutinated, with much cement.

Size: Topotypes are up to 600 microns in diameter. Specimens from the North Sea average 450 microns.

Observed occurrences: Cushman and Jarvis originally reported this species as Nonion cretacea form the type locality of the Lizard Springs Formation of Trinidad. Jarvis' original sample from Lizard Springs is from zone P5. In Trinidad, the stratigraphic range of $R$. jarvisi was reported by Kaminski et al. (1988) as upper Paleocene (zones P4-P5). In the flysch deposits at Zumaya in northern Spain, the morphotype transitional between $R$. jarvisi and Haplophragmoides walteri (Grzybowski) was found in zone P3b by Kaminski (1987). In the Central North Sea, $R$. jarvisi ranges into the $R$. bulimoides-D. seigliei zone (lower Oligocene). We have also found $R$. jarvisi in samples from the Paleocene of Tunisia (El Kef Section) and from offshore Angola. We have not observed this species on the Labrador Margin, in the deep Labrador Sea or in our samples from the Alpine-Carpathian region.
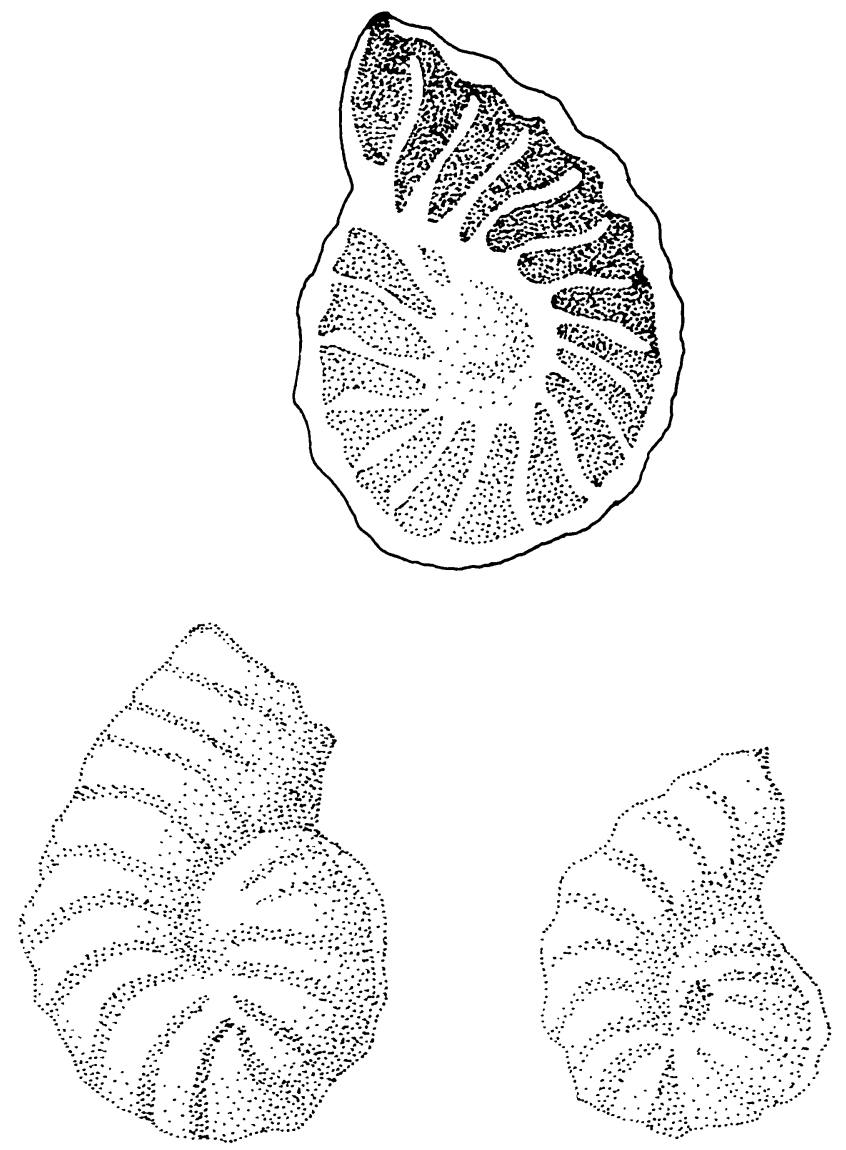

TEXT-FIGURE 2

Holotype and paratypes of Ammomarginulina aubertae, n. sp.

Known stratigraphic range: Upper Paleocene (P4) to lower Oligocene ( $R$. bulimoides-D. seigliei zone).

Bathymetric range: Bathyal.

Remarks: Reticulophragmoides jarvisi was originally thought to be calcareous (Cushman and Jarvis 1932; Thalmann 1932), but it has a finely agglutinated wall which in deeply buried strata is usually silicified. It was removed from the Nonionidae by Kaminski et al. (1988). As an agglutinated species, it is transitional in morphology between Haplophragmoides and the lenticular morphotypes of Reticulophragmium, such as $R$. amplectens. Its distinguishing features are its limbate sutures and the blind umbilical tube, which were first noticed

\section{PLATE 4}

Ammomarginulina aubertae, n. sp. metatypes

1a, b Labrador Margin, North Leif I-05 well, 2495 m, $\times 152$.

2a, b Labrador Margin, Flying Foam I-13 well, 4500-6400', $\times 157$. 3a, b Labrador Margin, Indian Harbour M-52 well, 10,450', $\times 162$. 


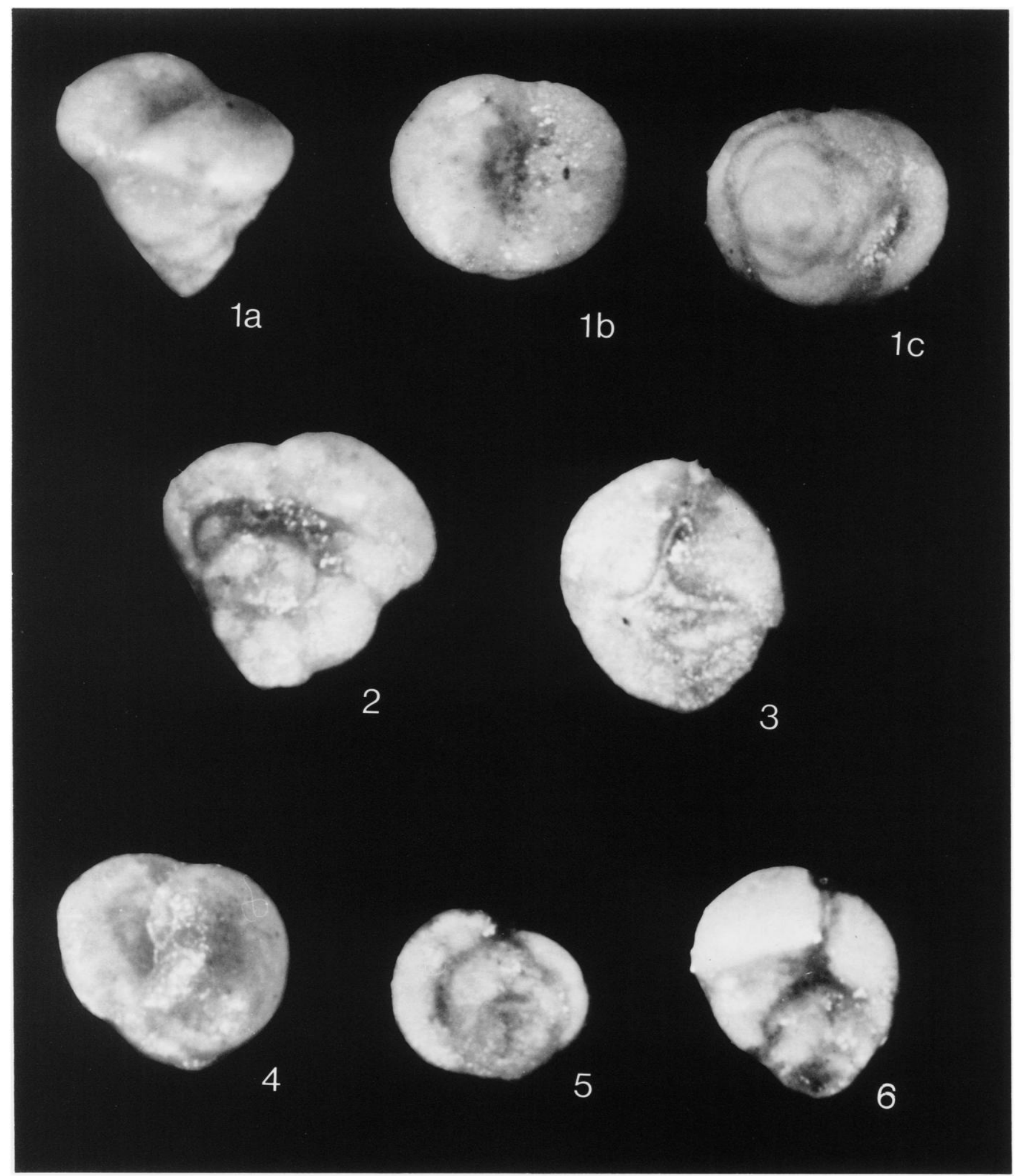

PLATE 5

Dorothia seigliei, n. sp.

1a-c Holotype, North Sea, UK Block 30, Shell 30/19-1 well, 8200' (R. bulimoides-D. seigliei zone), $\times 115$.
2-6 Paratypes, North Sea, UK Block 29, Shell 29/3-1 well, 6980-7220', × 115 . 
by Cushman and Jarvis (1932). Reticulophragmoides jarvisi probably evolved from an early form of Haplophragmoides walteri (Grzybowski) in the North Atlantic region during the middle Paleocene (zone P3b). Transitional specimens between the two species occur in Trinidad and Spain in zones $\mathrm{P} 3 \mathrm{~b}$ to $\mathrm{P} 4$. The topotypes of $R$. jarvisi from Trinidad differ from $H$. walteri in possessing the umbilical tube, limbate sutures and a $R$. amplectens-like lateral profile in apertural view. The specimens illustrated in plate 7 , figures $1 \mathrm{a}-2 \mathrm{~b}$ and in text-figure 4 are topotypes from the Lizard Springs Formation. These specimens tend to be about 150 microns larger and are thicker around the umbilicus than specimens from the Eocene and Oligocene of the Central North Sea. Although our specimens from the Lizard Springs Formation do not contain any alveoles, younger specimens of $R$. jarvisi from the uppermost Paleocene of offshore Angola develop a few alveoles in later chambers. This morphotype of $R$. jarvisi may be the ancestor of the Reticulophragmium amplectens (Grzybowski) lineage.

Reticulophragmoides sp. 5

Plate 8, figures $1 \mathrm{a}-4 \mathrm{c}$

Type specimen: Specimens are housed in the authors' collections.

Type level: Lower Oligocene (R. bulimoides-D. seigliei zone).

Type locality: Central North Sea, UK Block 30, Shell 30/ 19-1 well, 7000-8330 ft.

Diagnostic features: Test free, planispiral, involute, with shallowly depressed umbilicus. Test is comprised of 2 whorls, with 8 to 10 chambers in the last whorl. Periphery is broadly rounded. Proloculus is large. Chambers increase slowly in size. Sutures are straight, limbate, flush with the surface of the test. Early chambers have no alveoles. In later chambers the alveoles are concentrated near the sutures. Apertural face is low, with some coarse agglutinated grains. Aperture interiomarginal.

Size: Average diameter 450 microns. Thickness: 220 microns.

Observed occurrences: Oligocene of the Central North Sea.

Bathymetry: Bathyal.

Remarks: Differs from Reticulophragmoides jarvisi in its thicker test with a more broadly rounded periphery and in lacking a keel.

Spiroplectammina navarroana Cushman emend.

Plate 9, figures 1a-12; text-figure 5

Spiroplectammina navarroana CUSHMAN 1932, p. 96, pl. 11, fig. 14.

Textularia plummerae LALICKER 1935, p. 50, pl. 6, fig. 10.

Spiroplectammina lanceolata HUSS 1966, p. 36, pl. 5, figs. 16-20.

Type specimen: The holotype (USNM 371545) and paratype (USNM 26887) are housed in the Cushman Collection, U.S. Natural History Museum, Washington, D.C.

Type level: Maastrichtian, upper clay member of the Navarro Formation.
Type locality: Six miles east of Corsicana, Navarro County, Texas.

Diagnostic features: Test elongate, arched, tapered, initially planispiral, later biserial, with broadly rounded periphery. Chambers are approximately as high as they are broad and increase slowly in size as added. The final one or two chambers may be somewhat more inflated than earlier chambers. Sutures are distinct, initially inclined with respect to the long axis of the test, later perpendicular to the axis, becoming more incised towards the distal end of the test. Wall mediumcoarse to finely agglutinated. Aperture a high, narrow opening at the base of the last chamber.

Size: Mean length is 850 microns.

Observed occurrences: Spiroplectammina navarroana is a ubiquitous component of flysch-type agglutinated assemblages and it occurs at nearly every locality studied. It was originally described from the upper clay member of the $\mathrm{Na}$ varro Formation of Texas. In the Polish Carpathians, Geroch and Nowak (1984) reported this species as Spiroplectammina lanceolata from the Turonian to Maastrichtian. In Trinidad, Kaminski et al. (1988) reported $S$. navarroana from the upper Maastrichtian A. mayaroensis zone to the lower Eocene (P8). In the flysch deposits at Zumaya in northern Spain it ranges from zone P1c to P6b (Kaminski 1987). In the Central North Sea and Labrador Margin, its average last occurrence is in the lower Eocene S. patagonica zone (D'Iorio 1986; Gradstein et al. 1988). In ODP Hole 647A in the southern Labrador Sea, it was found in the lower and middle Eocene (Kaminski et al., in press). As Textularia plummerae, it was described from the Eocene Mexia clay member of the Wills Point Formation of Texas. Spiroplectammina navarroana has not been reported from the deep abyssal agglutinated fauna described by Krasheninnikov (1973, 1974), Hemleben and Troester (1984) and Moullade et al. (in press).

Known stratigraphic range: Turonian to Eocene.

Bathymetric range: Bathyal to upper abyssal.

Remarks: Cushman (1932) based his initial description of $S$. navarroana on broken specimens and he made no mention of an initial planispire. Only two of Cushman's specimens are preserved in the Cushman Collection. Cushman originally described $S$. navarroana as being "very slightly if at all tapering in the adult portion". Our examination of the holotype and paratype (text-figs. 5-2a, b, and 5-3a, b, respectively) revealed that they are short $(0.62$ and $0.47 \mathrm{~mm})$ biserial fragments which are not representative of the species. Specimens from other localities are usually longer and contain more pairs of biserial chambers. Unbroken specimens are rare, but complete specimens have a minute initial whorl of about 5 chambers and have a tapered, arching test (pl. 9, fig. 4). The holotype of Textularia plummerae Lalicker (1935) from the Eocene Mexia Clay of Texas (text-fig. 5-1a, b) is in our opinion, indistinguishable from $S$. navarroana from North Atlantic and Tethyan localities. The species $S$. lanceolata Huss (1966) from the upper Cretaceous of the Polish Carpathians was described as having 10 to 13 rows of biserial chambers and an initial planispire which is situated eccentric to the long axis of the test. The type specimens of S. lanceo- 


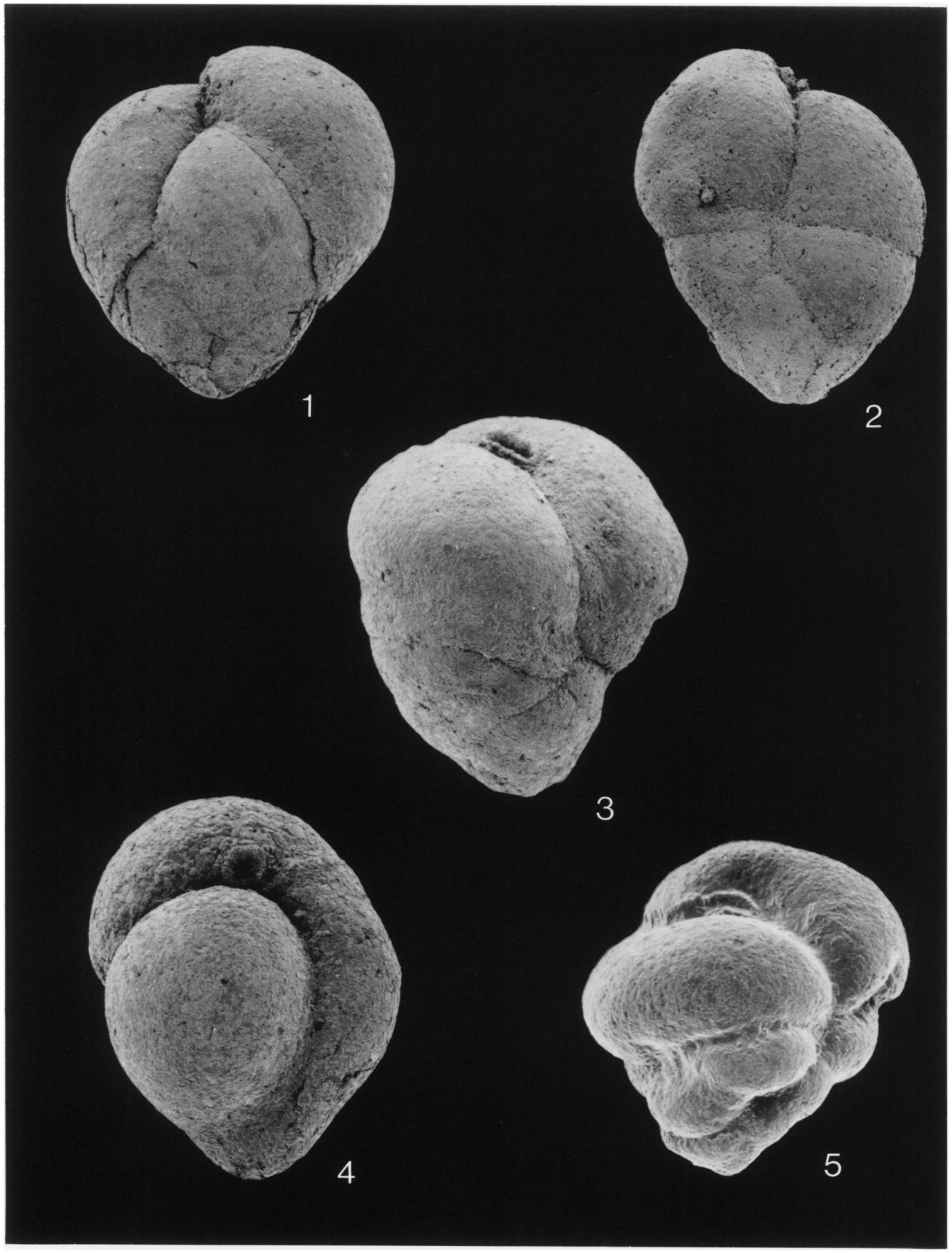



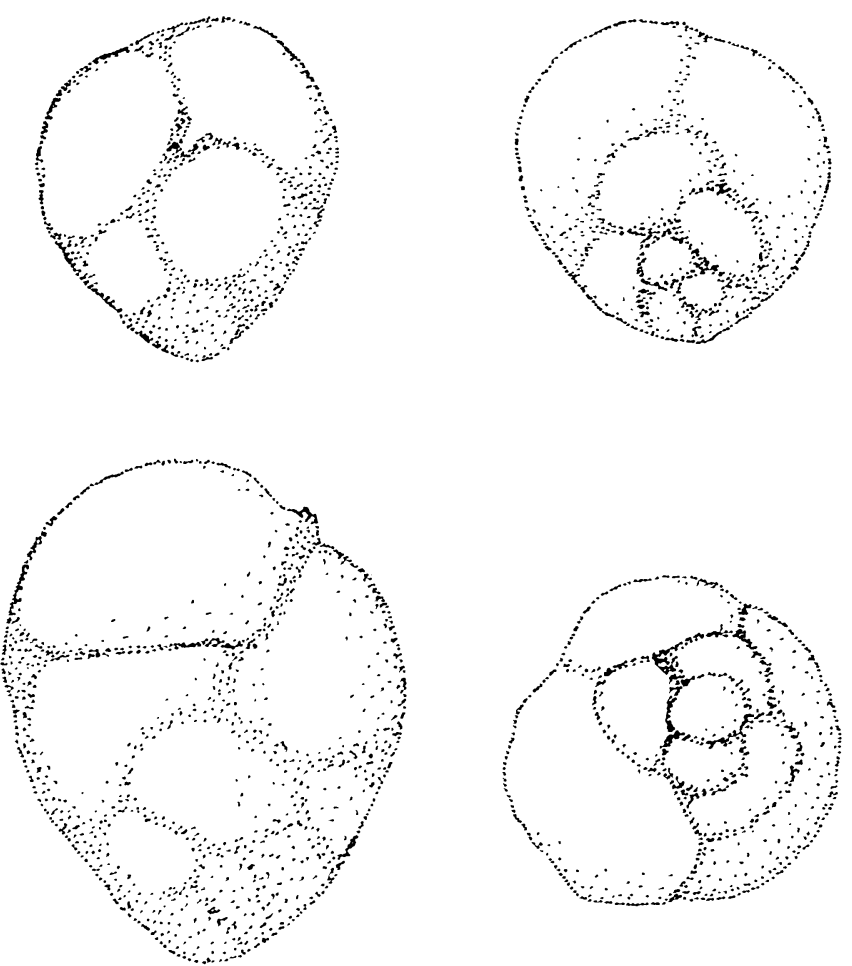

TEXT-FIGURE 3

Paratypes of Dorothia seigliei, n. sp.

lata are missing from the collections of the Polish state petroleum exploration company "NAFTA", but our topotype specimens from the Campanian Weglowka marls of Poland are identical to $S$. navarroana from the North Atlantic flyschtype assemblages. Spiroplectammina navarroana is variable in the size and nature of the agglutinated grains used in the construction of the test wall. The type specimens are comprised of relatively coarse material which includes some mafic grains, whereas specimens from Site 647 (pl. 9, fig. 3) are comprised of fine-grained pelagic material.

\section{DISCUSSION}

Biostratigraphy: The stratigraphic distribution of local last occurrences of over 250 foraminiferal taxa, including more than 80 agglutinated taxa in 58 North Sea and Labrador Margin wells (Table 1) was investigated using the ranking and scaling (RASC) method. This method is able to process
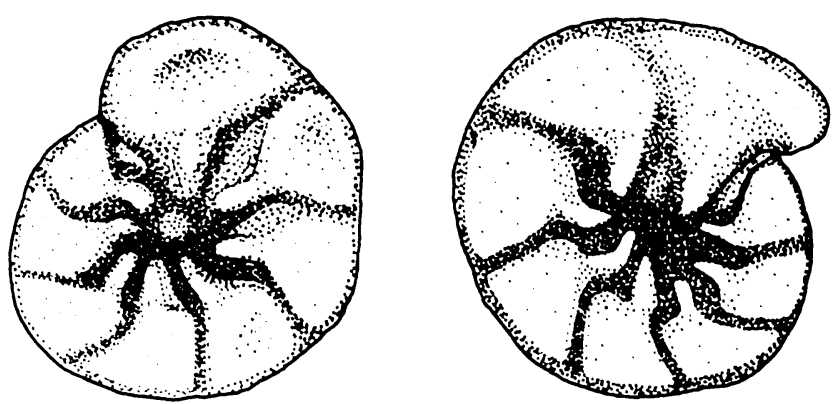

TEXT-FIGURE 4

Topotypes of Reticulophragmoides jarvisi.

a complex and noisy stratigraphic data set in an objective manner and produce a practical zonation. Previous RASC zonations, using fewer well data and fewer taxa for both regions were reported in Gradstein et al. (1985), D'Iorio (1986) and Gradstein et al. (1988). A more detailed biostratigraphy and subsurface correlation of the strata in these basins is in progress and will be reported elsewhere. Figure 6 shows the current Cenozoic biostratigraphic framework for the Labrador/Northern Grand Margin and the Central North Sea using RASC and the stratigraphic ranges of the new and emended taxa described in the previous section.

In the Central North Sea, the species Adercotryma agterbergi, n. sp., Dorothia seigliei, n. sp. and Reticulophragmoides sp. 5 occur from the Reticulophragmium amplectens zone (middle to upper Eocene) to the Rotaliatina bulimoides zone (lower Oligocene). These new taxa appear to be unique to the North Sea-Norwegian-Greenland Sea region. Along the Lab-
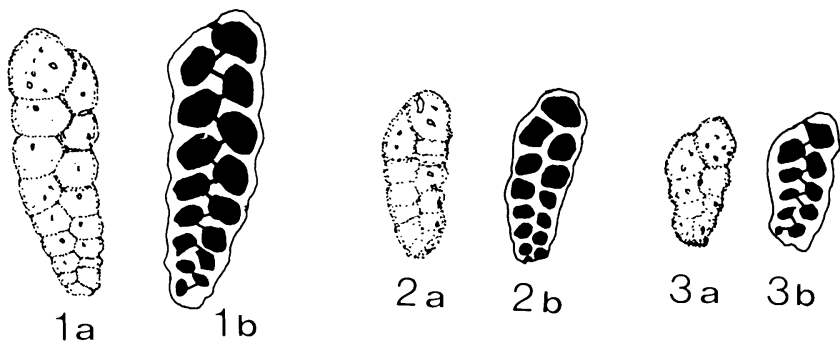

1 a

$1 \mathrm{~b}$

TEXT-FIGURE 5

1a, b. Holotype of Textularia plummerae (Cush. Coll. 21922). 2a, b. Holotype of Spiroplectammina navarroana; 3a, b. Paratype of Spiroplectammina navarroana.

\section{PLATE 6}

\section{Dorothia seigliei, n. sp.}

1-4 Metatypes, Norwegian-Greenland Sea, ODP Site 643, Cores 42-44 (Oligocene). 1. Sample 643A-42R-3, 71$74 \mathrm{~cm}, \times 298$. 2. Sample 643A-44R-3, 79-84 cm, $\times$ 242. 3. Sample 643A-44R-5, 79-84 cm, $\times 306.4$. Sample 643A-42R-3, 71-74 cm, × 570 .
5 Paratype, North Sea, UK Block 30, Shell 30/19-1 well, $8200^{\prime}, \times 480$. 


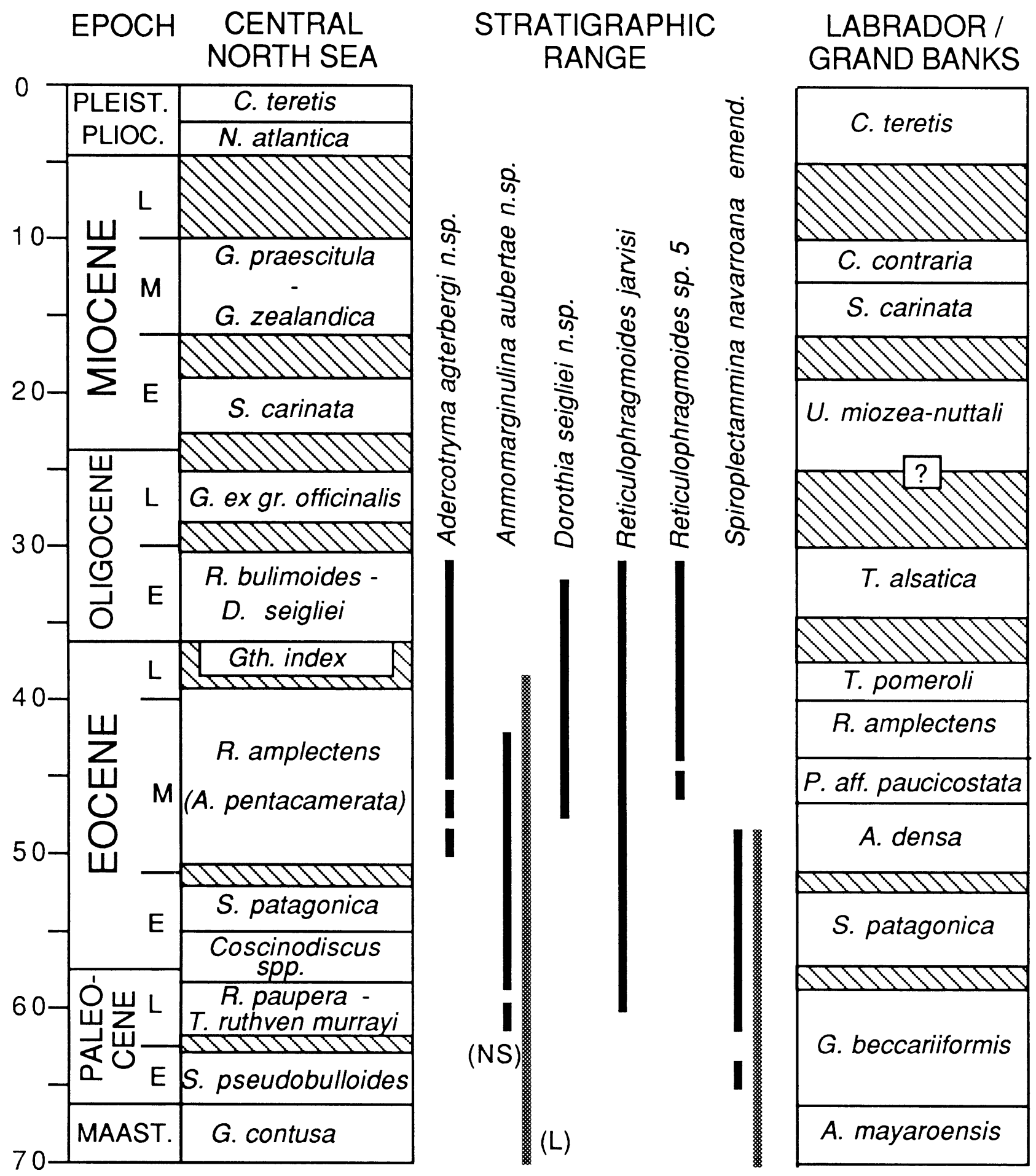

I $(\mathrm{NS})=$ North Sea $\quad(L)=$ Labrador Sea

* Dashed lines indicate uncertainty due to caving in rotary wells.

TEXT-FIGURE 6

Biostratigraphy of the six new and emended taxa in the North Sea and Labrador Sea. Columns indicate RASC zonations for the Central North Sea and Labrador Margin/Grand Banks wells. Scale is in millions of years. 


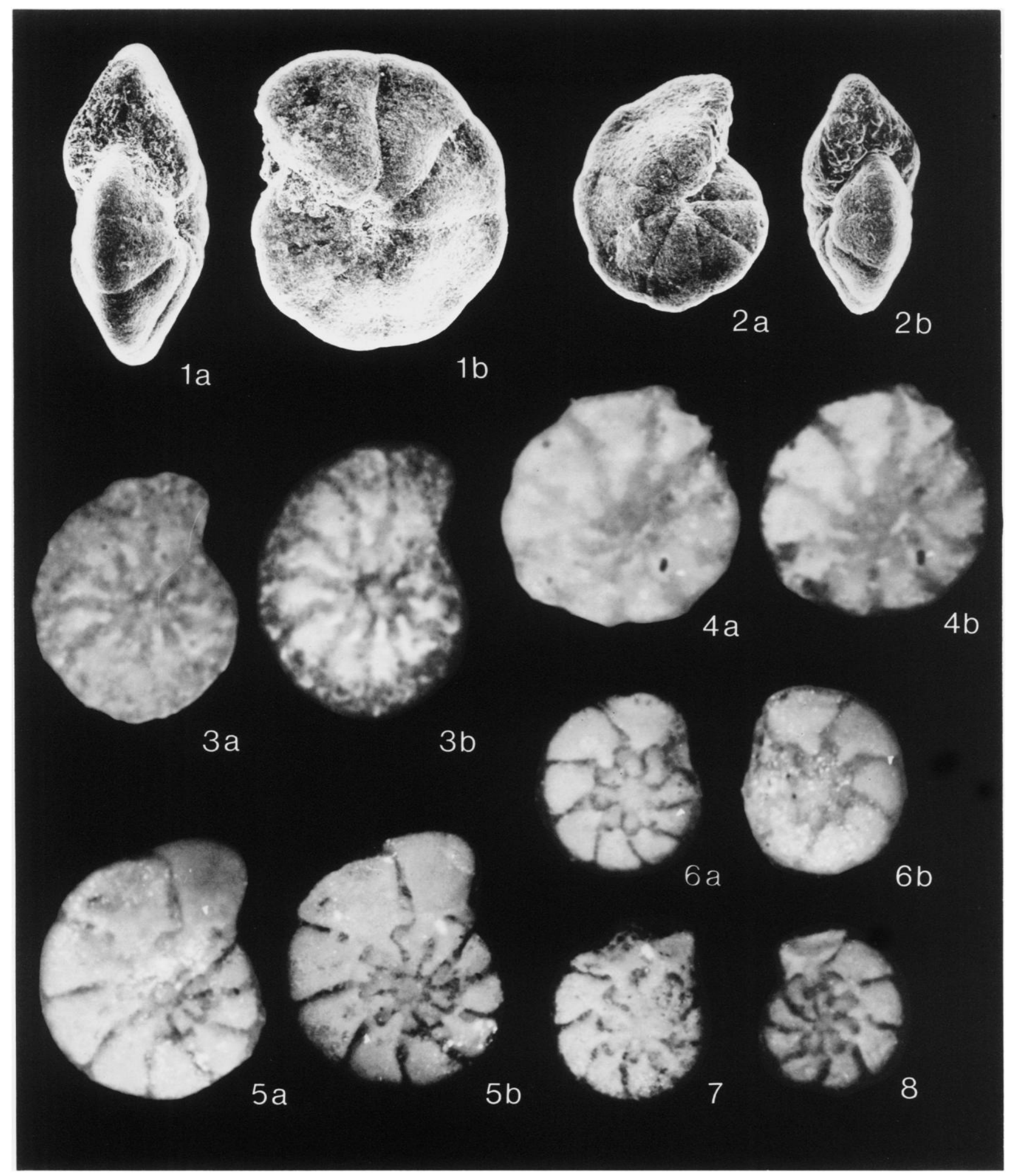

PLATE 7

Reticulophragmoides jarvisi

1a-2b Topotypes, Trinidad (Lizard Springs Formation), Ravine Ampelu, × 200 .

3a, b Ideotypes, Tunisia (El Kef Section), $\times 105$.

4a, b Ideotypes, Offshore Angola (upper Paleocene), $\times 88$. 5a-8 Ideotypes, North Sea. 5a, b. UK Block 21, BP 21/ 10-4 well, $2065 \mathrm{~m}, \times 115.6 \mathrm{a}$, b. UK Block 30, Shell 30/19-1 well, 8700-8800', $\times 115$. 7. UK Block 22, Shell 22/6-1 well, $6460^{\prime}, \times 115$. 8. UK Block 22, Shell 22/6-1 well, 6370', $\times 80$. 


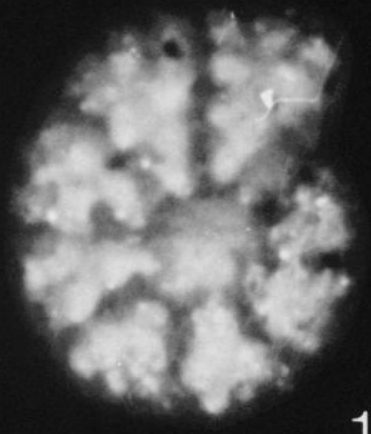

$1 a$

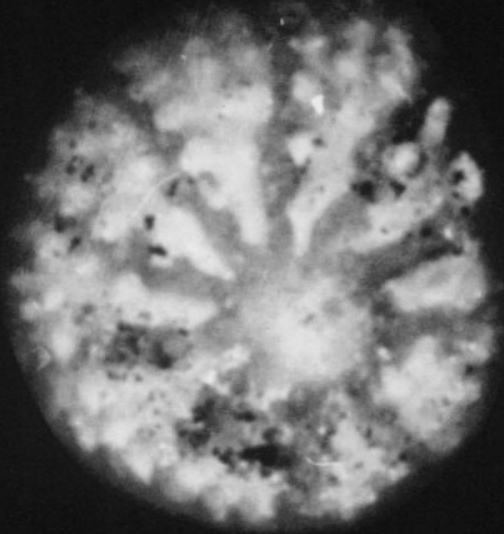

$2 a$

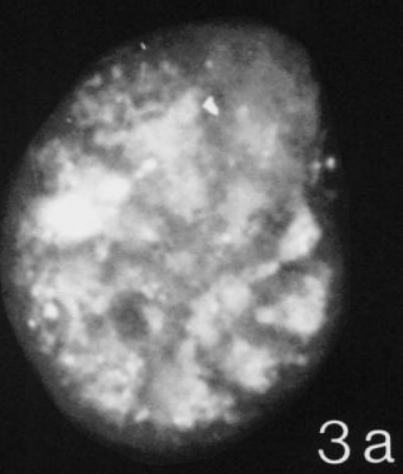

$3 a$

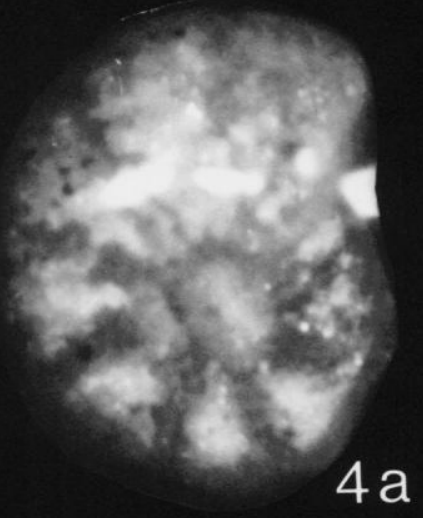

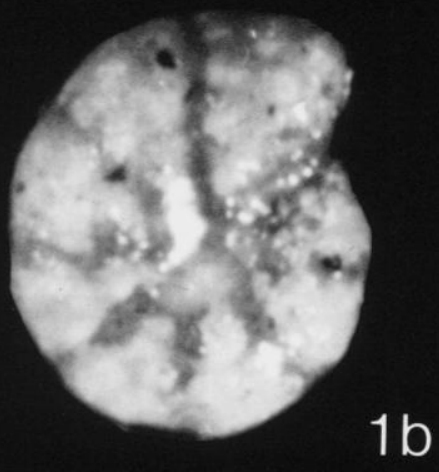
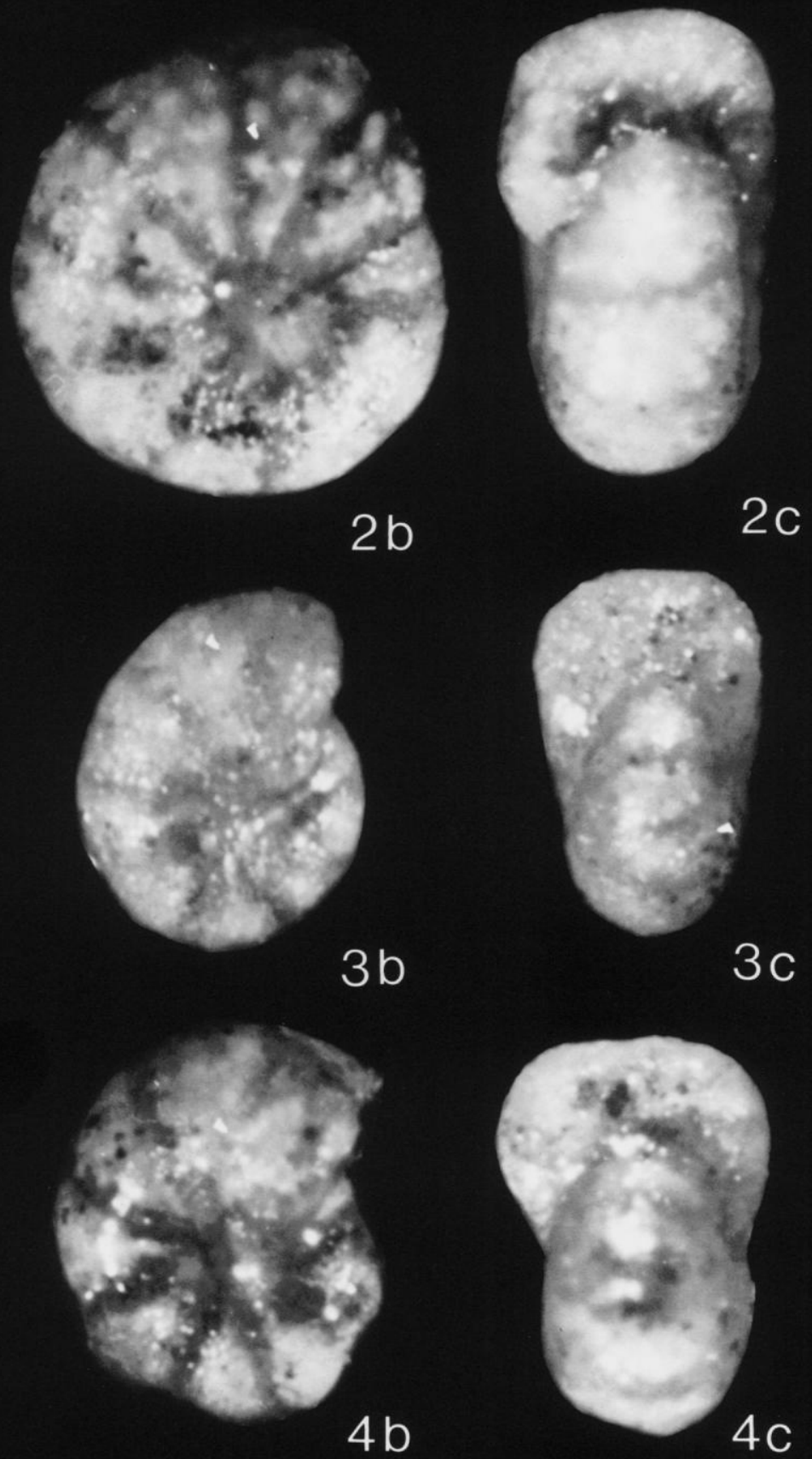

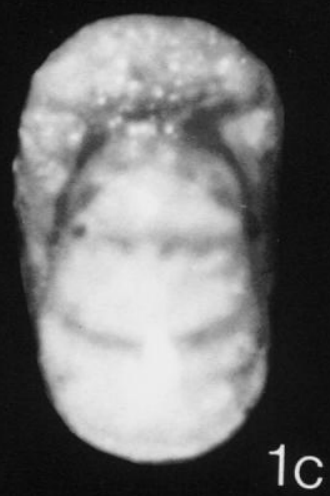

$1 \mathrm{C}$ 
rador Margin, Ammomarginulina aubertae, n. sp. ranges from the Abathomphalus mayaroensis zone (upper Maastrichtian) to the Reticulophragmium amplectens-Turborotalia pomeroli zone (upper Eocene). In the Central North Sea, A. aubertae, n. sp. ranges from the Subbotina pseudobuloides zone (Danian) to the $R$. amplectens zone (middle to upper Eocene). Reticulophragmoides jarvisi extends from the T. ruthven murrayi-R. paupera zone (Selandian) to the Rotaliatina bulimoides- $D$. seigliei zone (lower Oligocene) in the Central North Sea. It also occurs in the upper Paleocene of the lower Lizard Springs Formation (zones P4-P5) in Trinidad (Kaminski et al. 1988). A form transitional between Haplophragmoides walteri and $R$. jarvisi occurs in zone $\mathrm{P} 4$ in the Zumaya flysch of northern Spain. We have not observed $R$. jarvisi in Canadian Margin wells or in the western Tethyan alpine region, and we know of no occurrences of this species in the Eocene of the Atlantic region south of the Greenland-Scotland Ridge. In the Eocene to Oligocene, $R$. jarvisi appears to be restricted to the North Sea region. The species Spiroplectammina navarroana is common in all areas of the North Atlantic margin studied by us and extends from the upper Maastrichtian A. mayaroensis zone (in Trinidad and Labrador) into the middle Eocene Acarinina densa zone in Labrador Margin wells. Spiroplectammina navarroana ranges upward from the Turonian in the Carpathian flysch deposits (Geroch and Nowak 1984).

\section{ACKNOWLEDGMENTS}

We are grateful to the Ocean Drilling Program and to Shell, Mobil, British Petroleum, Total, Conoco and Phillips for providing sample material. Frank Thomas provided much appreciated assistance with SEM and light microscope photography, and Nelly Koziel did the manuscript layout. Our ideas on the taxonomic affinity of $R$. jarvisi have benefited from valuable discussions between MAK and Jean-Pierre Beckmann, Jeno Nagy, Stanislaw Geroch and Garry Jones. We thank Martin Buzas (Smithsonian), Fred Rögl (Vienna) and Stan Geroch (Kraków) for curating specimens. Mary Beth Baker, Fiona Cole, Stan Geroch, Bob Wynn Jones, Garry D. Jones, Charlie Schafer and Frank Thomas kindly reviewed the manuscript. MAK is supported by a postdoctoral fellowship from the Killam Trust of Dalhousie University. This is contribution no. 24188 of the Geological Survey of Canada and contribution no. 21 of the Deep-water Agglutinated Foraminifera Project.

\section{REFERENCES}

CUSHMAN, J. A., 1932. Textularia and related forms from the Cretaceous. Contributions from the Cushman Laboratory for Foraminiferal Research, 8:86-97.
CUSHMAN, J. A., and JARVIS, P. W., 1932. Upper Cretaceous foraminifera from Trinidad. Proceedings of the U.S. National Museum 80 , article 14:1-60.

D'IORIO, M. A., 1986. Integration of foraminiferal and dinoflagellate data sets in quantitative stratigraphy of the Grand Banks and Labrador Shelf. Bulletin of Canadian Petroleum Geology, 34: 277-283.

GEROCH, S., and NOWAK, W., 1984. Proposal of zonation for the late Tithonian-late Eocene, based upon arenaceous foraminifera from the outer Carpathians, Poland. Benthos ' 83 , 2nd International Symposium on Benthic Foraminifera (Pau, April 1983), pp. 225-239.

GRADSTEIN, F. M., AGTERBERG, F. P., BROWER, F. C., and SCHWARZACHER, W. S., 1985. Quantitative stratigraphy. D. Reidel Publishing Co., Dordrecht, 589 pp.

GRADSTEIN, F. M., and BERGGREN, W. A., 1981. Flysch-type agglutinated foraminiferal stratigraphy and the Maestrichtian to Paleogene history of the Labrador and North Seas. Marine Micropaleontology, 6:211-268.

GRADSTEIN, F. M., KAMINSKI, M. A., and BERGGREN, W. A., 1988. Cenozoic foraminiferal biostratigraphy, Central North Sea. In: Rögl, F., and Gradstein, F. M., Eds., Second Workshop on Agglutinated Foraminifera, Vienna 1986, Proceedings. Abhandlungen der Geologischen Bundesanstalt, 41:97-108.

HEMLEBEN, C., and TROESTER, J., 1984. Campanian-Maestrichtian deep-water foraminifers from Hole 543A, Deep Sea Drilling Project. In: Biju-Duval, B., Moore, J. C., et al., Initial Reports of the Deep Sea Drilling Project, Volume 78A:509-532. Washington, D.C.: U.S. Government Printing Office.

HUSS, J., 1966. Otwornice aglutynujace serii podslaskiej jednostki roponosnej Weglowki (Polskie Karpaty Fliszowe). Les foraminiferres agglutinants de la série soussilésienne de l'unite pétrolifere de Weglowka (Karpates flyschenses polonaises)-résumé, 63-71. Prace Geologiczne Polskiej Akademii Nauk, 34, 76 pp.

KAMINSKI, M. A., 1987. Cenozoic deep-water agglutinated foraminifera in the North Atlantic. Ph.D. thesis, Woods Hole Oceanographic Institution/Massachusetts Institute of Technology, Joint Program in Oceanography. WHOI-88-3, 262 pp.

KAMINSKI, M. A., and GEROCH, S., 1987. Two new species of Phenacophragma from the Paleogene of Trinidad and Poland. Micropaleontology, 33:185-188.

KAMINSKI, M. A., GRADSTEIN, F. M., and BERGGREN, W. A., in press. Paleogene benthic foraminiferal stratigraphy and paleoecology at Site 647, southern Labrador Sea. In: Arthur, M. A., Srivastava, S. D., et al., Proceedings, Initial Reports of Ocean Drilling Program Leg 105, vol. B.

KAMINSKI, M. A., GRADSTEIN, F. M., BERGGREN, W. A., GEROCH, S., and BECKMANN, J-P., 1988. Flysch-type agglutinated foraminiferal assemblages from Trinidad: taxonomy, stra-

\section{PLATE 8}

Reticulophragmoides sp. 5

1a-4c North Sea, UK Block 30, Shell 30/19-1 well, 7730', × 120 . 


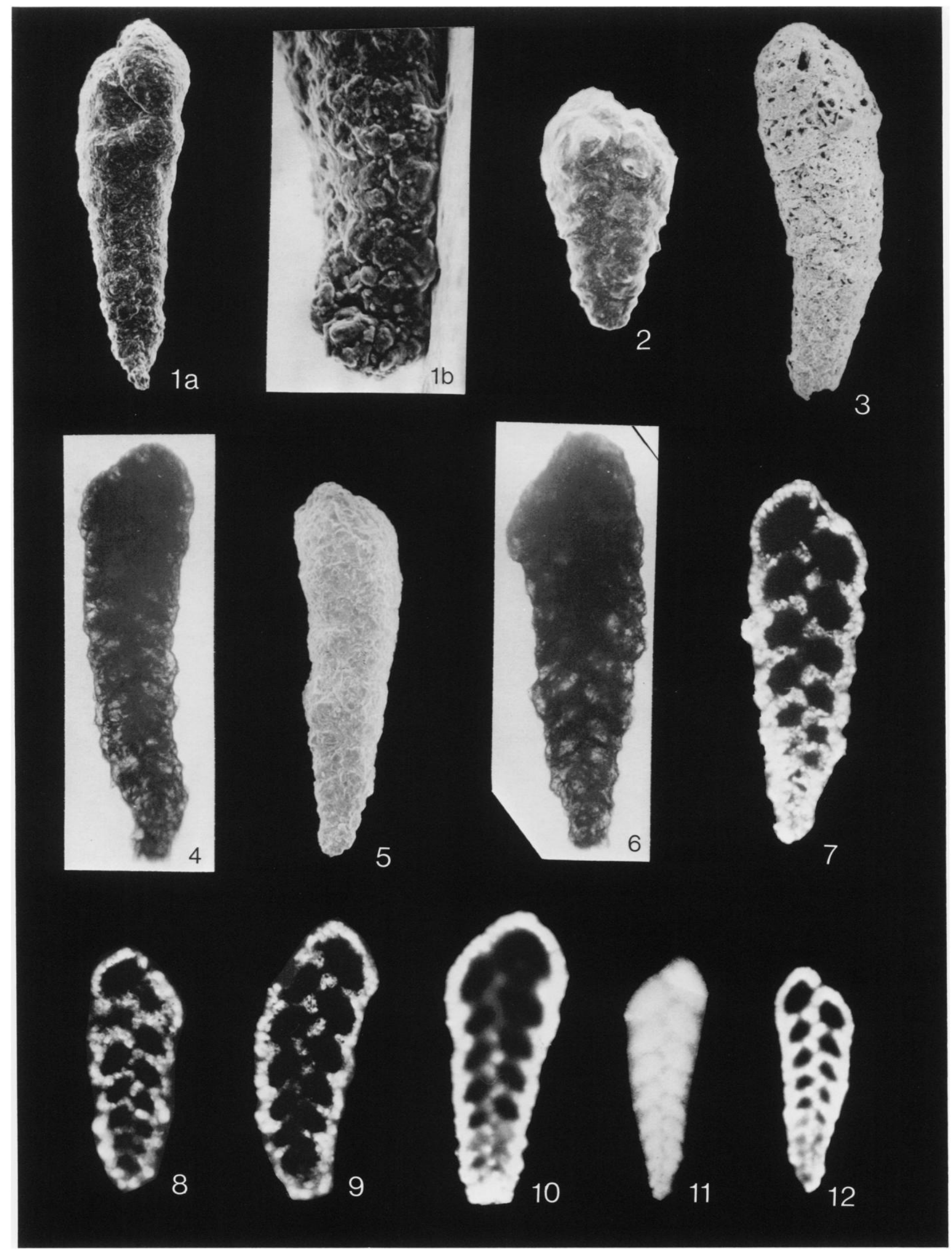


tigraphy and paleobathymetry. In: Rögl, F., and Gradstein, F. M., Eds., Second Workshop on Agglutinated Foraminifera, Vienna 1986, Proceedings. Abhandlungen der Geologischen Bundesanstalt, $41: 155-228$.

KRASHENINNIKOV, V. A., 1973. Cretaceous benthonic foraminifera, Leg 20, Deep Sea Drilling Project. In: Heezen, B. C., MacGregor, I. D., et al., Initial Reports of the Deep Sea Drilling Project, Volume 20:205-221. Washington, D.C.: U.S. Government Printing Office.

- 1974. Upper Cretaceous benthonic foraminifera, Leg 27, Deep Sea Drilling Project. In: Veevers, J. J., Hertzler, J. R., et al., Initial Reports of the Deep Sea Drilling Project, Volume 27:631667. Washington, D.C.: U.S. Government Printing Office.

KUHNT, W., 1987. Biostratigraphie und Paleoenvironment der externen Kreideserien des westlichen Rif und Betikum - ein Ansatz zur Rekonstruktion der Kreide-Palaeogeographie des Gibraltarbogens. Ph.D. thesis, Eberhard-Karls Universität, Tübingen, 271 pp.

LALICKER, C. G., 1935. New Tertiary Textulariidae. Contributions of the Cushman Laboratory for Foraminiferal Research, 11:3951 .

MILLER, K. G., GRADSTEIN, F. M., and BERGGREN, W. A., 1982. Late Cretaceous to early Tertiary agglutinated benthic foraminifera in the Labrador Sea. Micropaleontology, 28(1):1-30.

MORGIEL, J., and OLSZEWSKA, B., 1981. Biostratigraphy of the Polish External Carpathians based on agglutinated foraminifera. Micropaleontology, 27(1):1-30.

MORLOTTI, E., 1988. Late Cretaceous flysch-type agglutinated foraminifera from the Northern Italian Apennines. In: Rögl, F., and Gradstein, F. M., Eds., Second Workshop on Agglutinated Foraminifera, Vienna 1986, Proceedings. Abhandlungen der Geologischen Bundesanstalt, 41:265-286.

MOULLADE, M., KUHNT, W., and THUROW, J., in press. Agglutinated benthic foraminifers from upper Cretaceous variegated clays of the North Atlantic Ocean (DSDP Leg 93 and ODP Leg 103). Proceedings, Initial Reports of Ocean Drilling Program Leg 103, vol. B.

THALMANN, H. E., 1932. Nonion jarvisi, nom. nov. and Trochammina kellettae nom. nov. Eclogae Geologicae Helvetiae, 25:312313.

VERDENIUS, J. G., and VAN HINTE, J. E., 1983. Central Norwegian-Greenland Sea: Tertiary arenaceous foraminifera, biostratigraphy and environment. Proceedings of the First International Workshop on Arenaceous Foraminifera, 7-9 September, 1981. Continental Shelf Institute Publication, 108:174-224.

\section{APPENDIX A}

Agglutinated foraminiferal taxa observed in the Maastrichtian-Cenozoic Central North Sea and Labrador Margin wells.

\section{ASTRORHIZACEA Brady 1881}

1. Dendrophrya excelsa Grzybowski

2. Dendrophrya robusta Grzybowski

3. Rhabdammina discreta Brady

4. Rhizammina indivisa Brady

5. Bathysiphon spp.

6. Psammosphaera fusca Schultze

7. Psammosphaera scruposa (Berthelin)

8. Saccammina complanata (Franke)

9. Saccammina placenta (Grzybowski)

10. Thurammina spp.

11. Hyperammina dilatata Grzybowski

\section{AMMODISCACEA Reuss 1862}

12. Ammodiscus cretaceus (Reuss)

13. Ammodiscus glabratus Cushman and Renz

14. Ammodiscus latus Grzybowski

15. Ammodiscus peruvianus Berry

16. Ammodiscus planus Loeblich

17. Ammodiscus nagyi Kaminski

18. Ammolagena clavata (Jones and Parker)

19. Glomospira charoides (Jones and Parker)

20. Glomospira diffundens Cushman and Renz

21. Glomospira glomerata (Grzybowski)

22. Glomospira gordialis (Jones and Parker)

23. Glomospira irregularis (Grzybowski)

24. Glomospira serpens (Grzybowski)

25. Glomospirella grzybowskii (Jurkiewicz)

26. Glomospirella biedae Samuel

27. Glomospirella sp. 4

\section{RZEHAKINIDAE Cushman 1933}

28. Rzehakina epigona (Rzehak)

29. Rzehakina minima Cushman and Renz

30. Spirosigmoilinella compressa Matsunaga

31. Spirosigmoilinella sp. of Verdenius and Van Hinte (1983)

32. Sigmoilopsis schlumbergeri (Silvestri)

\section{PLATE 9}

Spiroplectammina navarroana Cushman, emend.

1-3 Labrador Sea, Paleogene. 1a-2. Dominion O-23 well. 10-12 Trinidad, Lizard Springs Formation, Paleocene. 3. ODP Site 647, Sample 67R-1, 40-43 cm.

4-9 Polish Carpathians, Weglowka Marls, Campanian. 


\section{HORMOSINACEAE Haeckel 1894}

33. Aschemonella grandis (Grzybowski)

34. Hormosina excelsa Dylazanka

35. Hormosina ovuloides (Grzybowski)

36. Hormosina ovulum (Grzybowski)

37. Hormosina trinitatensis Cushman and Renz

38. Hormosina velascoensis (Cushman)

39. Kalamopsis grzybowskii (Dylazanka)

40. Pelosina sp.

41. Reophax duplex Grzybowski

42. Reophax globosus Sliter

43. Reophax pilulifer Brady

44. Reophax subfusiformis Earland

45. Reophax splendidus Grzybowski

46. Reophax subnodosiformis (Grzybowski)

47. Subreophax scalaria (Grzybowski)

48. Subreophax pseudoscalaria Samuel

\section{LITUOLACEA de Blainville 1827}

49. Adercotryma agterbergi Gradstein and Kaminski, n. sp.

50. Ammobaculites agglutinans (d'Orbigny)

51. Ammobaculites deflexus (Grzybowski)

52. Ammobaculites jarvisi Cushman and Renz

53. Ammobaculites sp. 3 of Kaminski et al., in press

54. Ammobaculites sp. 4

55. Ammomarginulina aubertae Gradstein and Kaminski, n. sp.

56. Ammomarginulina sp. $\mathrm{G}$

57. Budashevaella multicamerata (Voloshinova and Budasheva)

58. Budashevaella trinitatensis (Cushman and Renz)

59. Cribrostomoides subglobosus (Sars)

60. Haplophragmoides eggeri Cushman

61. Haplophragmoides walteri excavatus Cushman

62. Haplophragmoides glabra Cushman and Waters

63. Haplophragmoides horrida (Grzybowski)

64. Haplophragmoides kirki Wickenden

65. Haplophragmoides porrectus Mjatliuk

66. Haplophragmoides retroseptus (Grzybowski)

67. Haplophragmoides ex gr. suborbicularis (Grzybowski)

68. Haplophragmoides walteri (Grzybowski)

69. Labrospira pacifica Krasheninnikov

70. Lituotuba lituiformis (Brady)

71. Recurvoides anormis Mjatliuk

72. Recurvoides deflexiformis (Noth)

73. Recurvoides dissonus Mjatliuk

74. Recurvoides gerochi Pflaumann

75. Recurvoides scitulus (Brady)

76. Recurvoides ex gr. walteri (Grzybowski)

77. Recurvoides varius Mjatliuk

78. Sphaerammina gerochi Hanzlikova

79. Trochamminoides acervulatus (Grzybowski)

80. Trochamminoides irregularis White

81. Trochamminoides subcoronatus (Grzybowski)

82. Trochamminoides subtrullisatus (Grzybowski)

\section{LOFTUSIACEA Brady 1884}

83. Reticulophragmium amplectens (Grzybowski)

84. Reticulophragmium garcilassoi (Frizzel)
85. Reticulophragmium cf. garcilassoi (Frizzel)

86. Reticulophragmium intermedia (Mjatliuk)

87. Reticulophragmium paupera (Chapman)

88. Reticulophragmoides jarvisi (Thalmann) emend. Gradstein and Kaminski

89. Reticulophragmoides $\mathrm{sp} .5$

90. Cyclammina cancellata Brady

91. Cyclammina placenta (Reuss)

92. Cyclammina rotundidorsata (Hantken)

\section{SPIROPLECTAMMINACEA Cushman 1927}

93. Spiroplectammina carinata (d'Orbigny)

94. Spiroplectammina carinata deperdita (d'Orbigny)

95. Spiroplectammina cubensis (Cushman and Bermudez)

96. Spiroplectammina aff. $S$. dentata (Alth)

97. Spiroplectammina excolata Cushman

98. Spiroplectammina navarroana Cushman emend. Gradstein and Kaminski

99. Spiroplectammina spectabilis (Grzybowski) emend. Kaminski 100. Vulvulina jarvisi Cushman

\section{TROCHAMMINACEA Schwager 1877}

101. Ammosphaeroidina pseudopauciloculata (Mjatliuk)

102. Cystammina aff. pauciloculata (Brady)

103. Praecystammina globigeriniformis Krasheninnikov

104. Trochammina altiformis Cushman and Renz

105. Trochammina aff. globigeriniformis Parker and Jones

106. Trochammina deformis Grzybowski

107. Trochammina ruthven murrayi Cushman and Renz

108. Trochammina subvesicularis Hanzlikova

\section{VERNEUILINACEA Cushman 1911}

109. Gaudryina cretacea (Karrer)

110. Gaudryina pyramidata Cushman

111. Guadryina aff. hiltermanni Meisl

112. Gaudryina sp. 10

\section{ATAXOPHRAGMIACEA Schwager 1877}

113. Arenobulimina americana Cushman

114. Arenobulimina dorbigny (Reuss)

115. Clavulinoides amorpha (Cushman)

116. Clavulinoides globulifera (Ten Dam and Sigal)

117. Dorothia oxycona (Reuss)

118. Dorothia retusa (Cushman)

119. Dorothia seigliei Gradstein and Kaminski, n. sp.

120. Karreriella bradyi (Cushman)

121. Karreriella coniformis (Grzybowski)

122. Karreriella conversa (Grzybowski)

123. Karreriella horrida Mjatliuk

124. Karreriella pokornyi Mjatliuk

125. Matanzia varians (Glaessner)

126. Martinotiella cylindrica (Bermudez)

127. Martinotiella sp. 2

128. Pseudobolivina variabilis (Vasicek)

129. Uvigerinammina jankoi Majzon 